\title{
The Appropriate Legal Standard and Sufficient Economic Evidence for Exclusive Dealing under Section 2: the FTC's McWane Case
}

\author{
Steven C. Salop \\ Georgetown University Law Center, salop@law.georgetown.edu \\ Sharis A. Pozen \\ Skadden, Arps, Slate, Meagher \& Flom LLP \\ John R. Seward \\ Skadden, Arps, Slate, Meagher \& Flom LLP
}

This paper can be downloaded free of charge from:

https://scholarship.law.georgetown.edu/facpub/1365

http://ssrn.com/abstract=2477448

This open-access article is brought to you by the Georgetown Law Library. Posted with permission of the author. Follow this and additional works at: https://scholarship.law.georgetown.edu/facpub

Part of the Antitrust and Trade Regulation Commons, and the Law and Economics Commons 
Draft: August 7, 2014

\title{
The Appropriate Legal Standard and Sufficient Economic Evidence for Exclusive Dealing under Section 2: the FTC's McWane Case
}

\author{
Steven C. Salop ${ }^{1}$ \\ Sharis A. Pozen \\ John R. Seward
}

\section{Introduction}

By a 3-1 margin, the FTC recently found McWane, Inc. ("McWane") liable for unlawful monopoly maintenance. ${ }^{2}$ McWane, a monopolist in the domestic pipe fittings industry, allegedly engaged in conduct aimed at maintaining its monopoly position through an exclusive dealing policy. The Commission found that the policy foreclosed entrants' access to distributors, and raised the costs of the only remaining independent competitor, Star Pipe Products, Ltd. ("Star"), thereby limited Star's scale, eliminating its ability to constrain McWane's prices. As a result, Star's limited entry did not lead McWane to reduce its prices.

The Dissent by Commissioner Joshua Wright ${ }^{3}$ differed from the Commission with respect to certain facts. ${ }^{4}$ More importantly for antitrust doctrine, however, Commissioner Wright

1 The authors are respectively Professor of Economics and Law, Georgetown University Law Center and Senior Consultant, Charles River Associates (Salop); Partner, Skadden, Arps, Slate, Meagher \& Flom LLP (Pozen); Associate, Skadden, Arps, Slate, Meagher \& Flom LLP (Seward). All opinions are our own and may not reflect the views of our colleagues or clients. Preparation of this article has not been carried or sponsored on behalf of any firm. We would like to thank James W. Attridge for helpful analysis and discussions, and Jonathan Baker and Carl Shapiro for comments on an earlier draft.

2 McWane, Inc., Docket No. 9351, at 2 (F.T.C. Jan. 30, 2014) [hereinafter McWane].

3 McWane, Inc., Docket No. 9351 (F.T.C. Jan. 30, 2014) (Dissenting Statement of Commissioner Joshua D. Wright) [hereinafter Dissent]. 
differed from the Commission with respect to the legal standard for monopolization through exclusive dealing and the economic analysis that should be carried out in such cases. These differences include the burden of proof and production on Complaint Counsel, as well as the type of evidence that is either relevant or must be proved before shifting the burden to the defendant under the rule of reason. The differences between the Commission's opinion and Commissioner Wright's dissent highlight a number of important and interesting issues in the economic analysis of exclusionary conduct and the determination of the proper legal and analytical antitrust standards applied to that monopolizing conduct.

In this article, we focus primarily on Commissioner Wright's dissenting statement because of its potential implications beyond just this case. His statement effectively proposes a new legal standard to govern exclusive dealing by a monopolist under Section 2 of the Sherman Act. This standard requires the plaintiff to show "clear evidence" of harm to competition in order to shift the burden to defendant to show procompetitive efficiencies. While this burden might have been appropriate if there were a strong, valid presumption that exclusive dealing by a monopolist is inherently likely to be procompetitive, adopting such a standard is misplaced, and the proposal to raise the burden of proof on the plaintiff beyond a showing of "probable effect" based on a preponderance of the evidence is unwise. This heightened burden is particularly inappropriate where (as here) the exclusivity is carried out by a monopolist who targeted all the independent entrants, and implemented the policy with the explicit purpose of hobbling their entry. It also seems especially unwarranted when the monopolist also lacks cognizable procompetitive justifications. Application of this heightened standard to interbrand exclusivity

4 There are numerous factual disputes between the Commission and Commissioner Wright. While we necessarily discuss the facts that have been alleged, our focus is placed on the economic analysis and legal standards, not the facts of the cases. 
restraints by monopolists runs counter to the case law and is not supported by either economic theory or applicable empirical evidence.

Commissioner Wright's legal standard further raises the plaintiff's burden by limiting the economic theories and types of evidence that would be relevant to a showing of harm to competition. In applying his heightened standard, he took a narrow view of the economic analysis of exclusion and the ways in which exclusion may harm competition. He focused only on the issue of whether the entrant (here, Star) would have reached "minimum efficient scale" (MES) absent the exclusive dealing. This approach did not separately trace out the other implications of the entrant facing higher distribution costs and how those higher costs might affect McWane's pricing incentives. Nor did it analyze how Star's scale might have been limited by the exclusive dealing to a level that permitted McWane to maintain monopoly prices, whether or not Star's output was less than MES. It thus failed to analyze all the ways in which the exclusionary conduct can cause harm to competition. In our view, these limitations on the economic theories of exclusion are not supported by modern economic analysis and serve only to weaken antitrust enforcement.

The proposed legal standard also limits in other ways how the plaintiff can make a prima facie showing. In our view, these limitations run counter to well-accepted legal and economic principles, which rely on reasonable inferences to establish competitive harm, in three key respects. First, the standard fails to take into account relevant structural evidence- such as the significance of McWane's market position and the importance of distributors-supporting a showing of harm to competition. Second, the standard fails to take into account the inferences that could reasonably be drawn from evidence that McWane's conduct had the purpose and intent of weakening the ability of independent entrants to compete on the merits. Third, the 
standard fails to draw any inference of harm to competition from the fact that McWane's conduct lacked cognizable efficiency benefits. Each of these findings after a full trial supported an inference that there was harm to competition. They also weakened contrary presumptions or make them inappropriate.

Commissioner Wright proposed to place the greatest weight on direct evidence of price and quantity effects. But, perhaps because of the skepticism inherent in his "clear evidence" standard, his analysis did not adequately take into account the direct evidence cited by the Commission of price differences between domestic fittings (where the exclusivity applied) and non-domestic fittings (where the exclusivity did not apply). Nor did his analysis credit evidence that McWane failed to reduce prices when Star entered. In comparing Star's growth during the exclusivity period and after he assumed it ended, his analysis failed to credit the fact that Star's market share almost doubled. His analysis also failed to take into account the possibility that the period of exclusivity could have adversely affected Star's subsequent ability to expand output after the exclusivity ended. It also did not recognize the possibility that Star's potential to expand could have had a competitive effect on McWane's prices in the period after the exclusivity ended, but which also would have reduced Star's growth rate.

In short, our conclusion is that this proposed legal standard is not an appropriate "enquiry meet for the case." Adoption of this standard (and the associated economic analysis) would lead to false negatives, under-enforcement, and under-deterrence of anticompetitive exclusion. It would provide perverse incentives for monopolists to use exclusive dealing to exclude new

5 Cal. Dental Ass'n. v. FTC, 526 U.S. 756, 781 (1999). 
entrants, even where the exclusives lack efficiency benefits. As a result, consumer welfare and the competitive process would be harmed.

To address these issues, Section II sets forth the basic framework for economic analysis of exclusive dealing and provides examples of how it has been applied by the courts for analyzing exclusive dealing arrangements. Section III reviews the facts found by the Commission and how they were used to conclude that McWane's conduct constituted anticompetitive monopolization. Section IV turns to Commissioner Wright's Dissent and analyzes in detail the factual, economic and legal issues raised there. Section V concludes.

\section{Analytic Framework for Analyzing Exclusive Dealing Arrangements}

Exclusive dealing arrangements may be challenged under Sections 1 and 2 of the Sherman $\mathrm{Act}^{6}$ and Section 5 of the FTC Act ${ }^{7}$. Section 3 of the Clayton Act also expressly prohibits exclusive dealing arrangements involving goods or commodities where the effect "may be to substantially lessen competition or tend to create a monopoly in any line of commerce."8 Although there are differences in the elements a plaintiff is required to prove under each statutory provision, the basic competitive concern relevant to exclusive dealing remains the same. ${ }^{9}$ Exclusive dealing may raise competitive concerns if it prevents a sufficient number of a supplier's competitors from distributing their products to a sufficient number of customers in a

\footnotetext{
15 U.S.C. $\S \S 1-2$.

15 U.S.C. $\$ 45$.

Clayton Act § 3, 15 U.S.C. § 14.

9 See Tampa Elec. Co. v. Nashville Coal Co., 365 U.S. 320, 327-28 (1961) (applying rule of reason analysis to exclusive dealing claims brought under Sherman Act $\S 1$ and Clayton Act $\S 3$ ); United States $v$. Microsoft Corp., 253 F.3d 34, 70 (D.C. Cir. 2001) ("The basic prudential concerns relevant to $\S \S 1$ and 2 are admittedly the same.”); Beltone Elecs. Corp., 100 F.T.C. 68, 87 (1982) (Commission applied Tampa Electric rule of reason analysis to claim under Section 5 of the FTC Act.).
} 
cost-effective way, and results in harm to competition. As the concurring opinion of four justices in Jefferson Parish explained:

In determining whether an exclusive dealing contract is unreasonable, the proper focus is on the structure of the market for the products or services in questionthe number of sellers and buyers in the market, the volume of their business, and the ease with which buyers and sellers can redirect their purchases or sales to others. $^{10}$

Exclusive dealing with distributors may reduce competition in violation of the antitrust laws in several ways. Exclusive dealing may raise rivals' costs by forcing them to utilize significantly more costly or less efficient avenues of distribution or manufacturing. ${ }^{11}$ The foreclosure also might facilitate coordination among the remaining distributors. Exclusive dealing may prevent new firms from entering the market or may limit their potential market shares. It may force existing rival firms out of the market or limit their ability to gain market share by denying them access to critical inputs or outlets. ${ }^{12}$ While the rivals may not be totally frozen out of the market, and may continue to be viable, their output and ability to compete may be significantly constrained. Where there are scale economies, the reduced output may magnify their cost increases. In each of these situations, the firm(s) instituting the exclusive dealing may

10 Jefferson Parish Hosp. Dist. No. 2 v. Hyde, 466 U.S. 2, 45 (1984) (O’Connor, J., concurring).

11 Microsoft, 253 F.3d at 70 (recognizing that "Microsoft's exclusive dealing arrangements ... had substantially excluded Netscape from 'the most efficient channels for Navigator to achieve browser usage share,' and had relegated it to more costly and less effective methods (such as mass mailing its browser on a disk or offering it for download over the internet)" (citations omitted)); see also 11 PHILLIP AREEDA \& HERBERT HOVENKAMP, ANTITRUST LAW: AN ANALYSIS OF ANTITRUST PRINCIPLES AND THEIR APPLICATION II 1804a (3d ed. 2011).

12 E.g., Interface Group, Inc. v. Mass. Port Auth., 816 F.2d 9, 11 (1st Cir. 1987) ("Exclusive dealing arrangements may sometimes be found unreasonable under the antitrust laws because they may place enough outlets, or sources of supply, in the hands of a single firm (or small group of firms) to make it difficult for new, potentially competing firms to penetrate the market."); Aspen Skiing Co. v. Aspen Highlands Skiing Corp., 472 U.S. 585 (1985); 11 AREEDA \& HOVENKAMP, Whi 11, II 1802c (“A set of strategically planned exclusive-dealing contracts may slow the rival's expansion by requiring it to develop alternative outlets for its products, or rely at least temporarily on inferior or more expensive outlets."). 
gain the power to raise or maintain supra-competitive prices. If rivals have higher costs or are unable to expand efficiently as a result of the exclusives, a monopolist will face less pressure to reduce its own prices. As a result, unless there is sufficient competition from other non-excluded competitors, or significant cognizable efficiency benefits, competition and consumers likely will be harmed.

Antitrust analysis focuses not just on whether any particular competitor are disadvantaged, but more importantly on whether the exclusive dealing results in an overall harm to competition. ${ }^{13}$ The harm to competition involves the impact on consumer welfare and the competitive process. Consumer welfare may be harmed when exclusive dealing causes prices to be raised. In the case of monopolists, exclusive dealing can maintain monopoly power by preventing prices from falling to more competitive levels. Exclusive dealing also may reduce product quality, service, and variety to the detriment of consumers. Over time, exclusive dealing may harm consumers and the competitive process by reducing the ability or incentive of rivals to invest in superior technologies and better products, perhaps relegating them to niche positions where they provide less of a competitive constraint on a dominant firm or monopolist. This in turn may diminish the incentives of the excluding firm to compete vigorously and to undertake investments in future product development and innovation.

There are two main mechanisms by which exclusive dealing can harm competition through foreclosure. As summarized in the concurring opinion in Jefferson Parish:

13 See Aspen Skiing, 472 U.S. at 605 (“"I]t is relevant to consider [the challenged conduct's] impact on consumers and whether it has impaired competition in an unnecessarily restrictive way."); Microsoft, 235 F.3d at 58 ("[T] $]$ o be condemned as exclusionary, a monopolist's act must have an 'anticompetitive effect.' That is, it must harm the competitive process and thereby harm consumers. In contrast, harm to one or more competitors will not suffice."). 
Exclusive dealing can have adverse economic consequences by allowing one supplier of goods or services unreasonably to deprive other suppliers of a market for their goods, or by allowing one buyer of goods unreasonably to deprive other buyers of a needed source of supply. ${ }^{14}$

Modern economic analysis distinguishes these two foreclosure mechanisms by which exclusive dealing with distributors can harm competition. These mechanisms can be denoted respectively by the terms "input foreclosure" and "customer foreclosure."15 Exclusive dealing can raise the input costs of one or more rivals by preventing or worsening their access to some or all distributors. ${ }^{16}$ Exclusive dealing similarly can reduce one or more rivals' sales and revenues by constraining their access to distributors and customers. Either way, the foreclosed rivals can have reduced ability or incentives to compete and expand. ${ }^{17}$ As a result, the excluding firm can gain power over price, that is, the power to raise or maintain supra-competitive pricing, or keep prices from falling. ${ }^{18}$ Foreclosure can also lead to or facilitate tacit or explicit coordination. ${ }^{19}$

14 Jefferson Parish, 466 U.S. at 45.

15 For the distinction between input and customer foreclosure in the context of vertical mergers, see Michael H. Riordan \& Steven C. Salop, Evaluating Vertical Mergers: A Post-Chicago Approach, 63 ANTITRUST L.J. 513 (1995). See also European Commission, Guidelines on the Assessment of Non-horizontal Mergers Under the Council Regulation on the Control of Concentrations Between Undertakings, 2008 O.J. (C 265) 6.

16 As famously summarized by Robert Bork, "In any business, patterns of distribution develop over time; these may reasonably be thought to be more efficient than alternative patterns of distribution that do not develop. The patterns that do develop and persist we may call the optimal patterns. By disturbing optimal distribution patterns one rival can impose costs upon another, that is, force the other to accept higher costs." ROBERT H. BORK, THE ANTITRUST PARADOX 156 (1978); see Aspen Skiing, 472 U.S. at 604 n.31 (quoting Bork).

17 Exclusive dealing also can harm competition by facilitating a "softening" of competition. For example, see Y. Joseph Lin, The Dampening-of-Competition Effect of Exclusive Dealing, 39 J. INDUS. ECON. 209 (1990); Daniel O'Brien \& Greg Shaffer, On the Dampening-of-Competition Effect of Exclusive Dealing, 42 J. INDUS. ECON. 215 (1993).

18 For the basic economic analysis, see Steven C. Salop \& David Scheffman, Raising Rivals' Costs, 73 AM. ECON. Rev. 267 (1983); Thomas G. Krattenmaker \& Steven C. Salop, Anticompetitive Exclusion: Raising Rivals' Costs to Achieve Power over Price, 96 YALE L.J. 209 (1986). For one general application of the theory to exclusive dealing, see Jonathan M. Jacobson, Exclusive Dealing, "Foreclosure," and Consumer Harm, 70 ANTITRUST L.J. 311, 347-64 (2002). 
Exclusive dealing can also involve both types of foreclosure occurring together in an interrelated way. ${ }^{20}$ Customer foreclosure can raise the foreclosed rivals' costs, and input foreclosure can reduce their revenues and limit their ability to expand.

\section{A. Input Foreclosure}

Exclusive dealing can raise entrants' or existing rivals' costs by “input foreclosure,” that is, by materially raising their costs or eliminating their efficient access to critical inputs. ${ }^{21}$ These inputs can involve manufacturing inputs, such as raw materials, intellectual property, or distribution. Distribution can be understood as an input, and raising rivals' costs of distribution can weaken their ability and incentives to expand. ${ }^{22}$ For example, by excluding its rivals' access to an efficient distribution system or other input, a monopolist can reduce the rivals' ability to induce downward pricing pressure, and so can permit the monopolist to maintain its monopoly power in the face of entry.

Input foreclosure can be so severe that the foreclosed rivals will exit from the market or be deterred from attempting entry. But even if a rival can cover its costs and remain viable, it

19 See JTC Petroleum Co. v. Piasa Motor Fuels, 190 F.3d 775, 780 (7th Cir. 1999); Elizabeth Granitz \& Benjamin Klein, Monopolization by “Raising Rivals' Costs”: The Standard Oil Case, 39 J.L. \& ECON. 1 (1996).

20 Economists categorize the mechanisms of harm from exclusionary conduct in various ways. For other examples, see Jonathan B., Exclusion as a Core Competition Concern, 78 AnTITRUST L.J. 527, 538-43 (2013) [hereinafter Core Concern]; C. Scott Hemphill \& Tim Wu, Parallel Exclusion, 122 YALE L.J. 1182 (2013).

21 Riordan \& Salop, supra note 15, at 528-550. Janusz Ordover et. al., Equilibrium Vertical Foreclosure, 80 AM. ECON. REV. 127 (1990). In this analytic framework, it is often useful and valid to characterize distributors as suppliers of a distribution services input, rather than simply as customers. See Krattenmaker \& Salop, supra note 18, at 226.

22 See BORK, supra note 16, at 156 ("By disturbing optimal distribution patterns one rival can impose costs upon another, that is, force the other to accept higher costs.”); Aspen Skiing Co. v. Aspen Highlands Skiing Corp., 472 U.S. 585, 604 n.31 (1985) (quoting Bork); United States v. Dentsply Int'l, Inc., 399 F.3d 181, 191 (3d Cir. 2005); United States v. Microsoft Corp., 253 F.3d 34, 70 (D.C. Cir. 2001). 
will be a weaker and less efficient competitor if its distribution or other input costs are higher. A competitor will have the incentive to raise its prices and/or restrict its output when its marginal costs are increased, even if it earns enough revenue to cover its costs. Similarly, even if the rival can remain viable by engaging in direct distribution or using less efficient distributors, its ability to constrain the pricing of the excluding firm will be lessened if its costs are higher or if its output is constrained to a low level. ${ }^{23}$

Some commentators erroneously narrow their focus solely on the whether the foreclosure will prevent rivals from reaching "minimum efficient scale" (MES). ${ }^{24}$ But the conditions under which foreclosure can reduce competition are not limited to a failure to achieve MES. ${ }^{25}$ Even if a viable rival is able to reach the MES output level (where its average costs bottom out), it costs may be significantly raised by exclusionary conduct and market prices may be higher as a result. Other commentators erroneously narrow their focus solely on whether the foreclosure will raise

23 This reasoning also explains why a "total foreclosure" standard would lead to false negatives. It is not necessary to cause a rival to exit in order for exclusive dealing to have anticompetitive effects. Raising rivals' costs or restricting their output to a lower level can permit a dominant firm or monopolist profitably to raise or maintain supra-competitive prices.

24 Joshua D. Wright, Moving Beyond Nä̈ve Foreclosure Analysis, 19 GEO. MASON L. REV. 1163, 1163-64 (2012) [hereinafter Nä̈ve Foreclosure]; see also Benjamin Klein, Exclusive Dealing as Competition for Distribution "On the Merits", 12 GEO. MASON. L. REV. 119, 122-28 (2003). This analysis could be applied to customer foreclosure as well as input foreclosure.

25 Foreclosure also can cause a rival to exit by preventing it from reaching "minimum viable scale (MVS)." But, these are not the only relevant conditions. For example, even if the competitor remains viable and also reaches MES (the scale where its average costs bottom out), its marginal and average costs may be raised by the foreclosure, so they are not truly minimized. The 1992 Horizontal Merger Guidelines explained the difference between minimum viable scale and minimum efficient scale in the context of merger analysis. "The concept of minimum viable scale ("MVS") differs from the concept of minimum efficient scale ("MES"). While MES is the smallest scale at which average costs are minimized, MVS is the smallest scale at which average costs equal the premerger price." U.S. DEP'T OF JUSTICE \& FED. TRADE COMM'N, HORIZONTAL MERGER GUIDELINES § 3.3, at 28 n.29 (1992) [hereinafter 1992 HORIZONTAL MERGER GUIDELINES]. In the context of exclusive dealing by a monopolist, the relevant price might be either the monopolist's pre-entry or post-entry price, depending on the exact question being analyzed. 
rivals' costs by so much that the rivals will not be viable. ${ }^{26}$ But, even if the rivals remain viable, suffering higher costs will reduce their competitive effectiveness and may permit the excluding firm to raise or maintain supra-competitive prices.

In the context of monopolization, these cost increases can occur if exclusive dealing by a monopolist prevents competitors from accessing an efficient distribution system or when it leads to the rivals having to use a higher cost manufacturing method. Exclusive dealing also might permit a rival to remain viable, but restrict the rival's scale of production by increasing its costs of expansion. If a monopolist can inflict such higher costs or output restrictions on its smaller competitors and new entrants, the monopolist will gain the power to maintain supra-competitive prices. ${ }^{27}$ Similarly, an excluding firm with market power may gain the ability to increase its prices. This anticompetitive effect can occur even if the rivals remain viable and are able to operate at MES or above.

The anticompetitive concerns with input foreclosure have been recognized in cases as diverse as JTC Petroleum ${ }^{28}$ and Microsoft. ${ }^{29}$ In JTC Petroleum, Judge Posner described a cartel of highway contractors who applied asphalt to roads and conspired with asphalt suppliers to raise the costs of a maverick competitor. In Microsoft, the D.C. Circuit condemned Microsoft's exclusive arrangements with computer manufacturers and Internet Access Providers that promoted the Internet Explorer web browser over the competing Netscape web browser. In

${ }^{26}$ Daniel A. Crane \& Graciela Miralles, Toward a Unified Theory of Exclusionary Vertical Restraints, 84 S. CAL. L. REV. 605, 646 (2011).

27 See Krattenmaker \& Salop, supra note 18, at 246-47 ("Raising Barriers to Entry").

28 JTC Petroleum Co. v. Piasa Motor Fuels, Inc., 190 F.3d 775, 777 (7th Cir. 1999).

29 United States v. Microsoft Corp., 253 F.3d 34, 71 (D.C. Cir. 2001) (affirming the District Court's finding that "Microsoft had substantially excluded Netscape from "the most efficient channels for Navigator to achieve browser usage share,' and had relegated it to more costly and less effective methods.") (internal citations omitted). 
doing so, the court found it sufficient that Microsoft's practice forced Netscape to adopt more costly and less effective distribution methods, even though Microsoft had not "completely excluded Netscape" from the market. ${ }^{30}$ As discussed below, input foreclosure also was an issue in the Dentsply ${ }^{31}$ exclusive dealing case.

\section{B. Customer Foreclosure}

Customer foreclosure focuses on the impact of losing efficient access to customers, including distributor customers. ${ }^{32}$ Customer foreclosure by a monopolist can injure competitors and harm competition in several distinct ways. First, the customer base of an entrant or small rival may be limited to such a degree that it is unable to earn sufficient profits to cover its costs and remain viable in the market. If anticipated sales likely would fall below this "minimum viable scale (MVS)," an entrant would lack an incentive to enter and an existing competitor would have the incentive to exit. ${ }^{33}$ Second, the entrant or competitor may remain viable, but customer foreclosure may limit its output to a low level and constrain its ability to expand

30 Id. at 69-71; United States v. Denstply Int'l, Inc., 399 F.3d 181, 191 (3d Cir. 2005) ('The test is not total foreclosure, but whether the challenged practices bar a substantial number of rivals or severely restrict the market's ambit."); ZF Meritor, LLC v. Eaton Corp., 696 F.3d 254, 283 (3d Cir. 2012) (“"[T]otal foreclosure' is not required for an exclusive dealing arrangement to be unlawful ...."), cert. denied, 133 S. Ct. 2025 (2013).

31 Dentsply, 399 F.3d at 181.

32 As noted earlier, supra note 14, Justice O'Connor observed in her concurring opinion in Jefferson Parish, "[e]xclusive dealing can have adverse economic consequences by allowing one supplier of goods or services unreasonably to deprive other suppliers of a market for their goods . ..." Jefferson Parish Hosp. Dist. No. 2 v. Hyde, 466 U.S. 2, 45 (1984) (O'Connor, J., concurring).

33 As explained in the 1992 Horizontal Merger Guidelines: "Minimum viable scale is the smallest average annual level of sales that the committed entrant must persistently achieve for profitability at premerger prices.” 1992 HORIZONTAL MERGER GUIDELINES, § 3.3, at 28. This is different from whether the entrant or competitor is able to achieve the MVS. 
profitably. ${ }^{34}$ Third, such customer foreclosure may permit the rival to remain in the market, but may reduce its incentives over time to invest, which can thereby relegate it to a niche position where it will provide less of a constraint on the pricing of the excluding firm(s). ${ }^{35}$

In a monopolization matter, competition may be harmed in all these situations because the monopolist will not be forced to engage in any or as much price competition. Instead, the monopolist will have the power to maintain supra-competitive prices. In the case where the entrant remains viable but with limited output, the monopolist may have the incentive to maintain monopoly prices while ceding a small market share to the entrant. Or, the monopolist may reduce prices, but only in a limited way because the constrained competitor will not pose a significant threat.

The condemned conduct in Lorain Journal Co. v. United States ${ }^{36}$ provides a classic example of customer foreclosure. Lorain Journal enjoyed a "complete daily newspaper monopoly of local advertising" in Lorain, Ohio, distributing its paper to 99 percent of families in the area. ${ }^{37}$ The journal adopted a policy of refusing to accept local advertising from any Lorain County advertiser who also advertised with WEOL, a local radio station that recently entered the market. ${ }^{38}$ The policy caused many local merchants to stop advertising with the radio station,

\footnotetext{
34 As noted earlier, supra text accompanying notes 23-26, this involves more general conditions than simply preventing the competitor from reaching MVS or MES. If output is restricted to a low level, the rival will not provide less of competitive constraint, even if that low output level exceeds MVS and MES.

35 For a sample of relevant economics articles related to customer foreclosure, see Eric B. Rasmusen et al., Naked Exclusion, 81 AM. ECON. REV. 1137, 1140-43 \& n.4 (1991); Ilya R. Segal \& Michael D. Whinston, Naked Exclusion: Comment, 90 AM. ECON. REV. 296, 297 (2000); Michael D. Whinston, Tying, Foreclosure, and Exclusion, 80 AM. ECON. REV. 837, 839 (1990); Dennis W. Carlton \& Michael Waldman, The Strategic Use of Tying to Preserve and Create Market Power in Evolving Industries, 33 RAND J. ECON. 194, 196 (2002).

36342 U.S. 143 (1951).

37 Id. at 149-50.

38 Id. at 148.
} 
creating a dangerous probability of the radio station going out of business had the Journal's conduct not been enjoined by the lower court. ${ }^{39}$ The Supreme Court affirmed the lower court's holding that the exclusive dealing constituted an attempted monopolization in violation of Section 2 of the Sherman Act by depriving the radio station of a market for its advertising air time. $^{40}$

Input and customer foreclosure also can occur simultaneously, as when a rival's costs are raised through input foreclosure and its revenues reduced through customer foreclosure. When this occurs, their impacts can be mutually reinforcing. The higher costs from input foreclosure can lead the rival to be unable to access certain customers, which then can cause it to exit or be neutralized. If marginal (variable) costs are higher when output is lower, customer foreclosure can lead to a rival having such higher costs as a result of having a lower scale of production. ${ }^{41}$ Or, if a rival's sales are restricted by customer foreclosure, the rival may be unable to negotiate low input prices with certain suppliers. Or the rival may find it uneconomical to adopt a more efficient technology that requires a high scale of production to cover its fixed costs.

Dentsply $^{42}$ is a case that focused on customer foreclosure but where input foreclosure also appears to be involved. The defendant Dentsply, a manufacturer of artificial teeth who held a 75 to 80 percent share of the relevant market, adopted a policy (known as "Dealer Criterion 6") of refusing to sell to any dealer who added a competing artificial tooth line to its product offering. Although competing manufacturers could, and did, sell directly to customers, the court found

39 Id. at 150

$40 I d$. at 154 .

41 This particular point also would be relevant to a situation where the competitor is unable to expand to an output level closer to MES.

42 United States v. Dentsply Int'l, Inc., 399 F.3d 181 (3d Cir. 2005). 
that distributing artificial teeth through dealers had lower transactions costs ${ }^{43}$ and other advantages over direct distribution, and acted as the "gateway[]" to dental laboratory customers. ${ }^{44}$ The Third Circuit thus concluded that Dealer Criterion 6 was "a solid pillar of harm to competition" because "[i]t help[ed] keep sales of competing teeth below the critical level necessary for any rival to pose a real threat to Dentsply’s market share." ${ }^{45}$

The case law, however, does not condemn every instance of exclusive dealing that somehow interferes with a rival's ability to get its product to market through input or customer foreclosure. For example, the Ninth Circuit, in Omega Environmental, Inc. v. Gilbarco, Inc., ${ }^{46}$ held that the record evidence was insufficient to support a jury's finding that Gilbarco's exclusive dealing violated Section 3 of the Clayton Act. In that case, Gilbarco instituted a policy of dealing only with distributors who sold its line of retail gasoline dispensers exclusively. Unlike the situation in Microsoft and Dentsply, the court found that selling through gasoline distributors was not necessarily the only efficient route to market. Rather, the court found that there was "undisputed evidence that direct sales to end-users [was] an alternative channel of distribution," with the number two manufacturer, Dresser, making 73 percent of its sales without the aid of a distributor. ${ }^{47}$ In addition, the evidence showed that Schlumberger was able to enter the gasoline dispenser market and successfully expand its sales, notwithstanding Gilbarco's

\footnotetext{
${ }^{43}$ Id. at $192-93$.

44 Id. at 193.

45 Id. at 191.

$46 \quad 127$ F.3d 1157 (9th Cir. 1997).

47 Id. at 1163.
} 
exclusive dealing. ${ }^{48}$ Given its findings, the court did not condemn the challenged exclusive dealing arrangement.

\section{Harm to Competition}

The fact that one or more competitors are injured by exclusive dealing does not necessarily mean that consumers will be harmed. There may be procompetitive benefits of the exclusive dealing. Moreover, even if there are no such benefits, consumer harm may be prevented by the existence of and continued competition from a sufficient number of nonexcluded competitors. These other competitors might prevent the excluding firm or firms from achieving, enhancing or maintaining market power. As summarized by Krattenmaker and Salop, consumer harm involves "power over price," that is, not just "rais[ing] rivals' costs."49 "Power over price," is the power to raise or maintain supra-competitive prices. ${ }^{50}$

In carrying out this competitive effects analysis, it is important to observe that the loss of a single rival may have little impact if there is sufficient continued competition from other competitors. That continued competition can prevent the excluding firm from gaining power over price. This outcome can occur if sufficient other rivals are not foreclosed from the critical input and the remaining competitors do not coordinate. ${ }^{51}$ It also can occur when those competitors' costs are not raised by the foreclosure because they have access to other efficient alternatives.

\footnotetext{
48 Id. at 1164.

49 Krattenmaker \& Salop, supra note 18, at 242-43.

50 Id.

51 See also Hemphill and Wu, supra note 20.
} 
However, when the excluding firm is a monopolist and its exclusionary conduct raises the costs of the only entrant (or all the most-likely entrants) into the market, that cost-raising conduct more likely will give the monopolist power over price, and cause harm to competition and consumers. Because monopolists charge prices that exceed their costs, successful entry into a monopoly market generally leads to lower prices, even if the viable entrants are less efficient than the monopolist. If exclusionary conduct targets all the most likely potential entrants, and there are no other unexcluded rivals to replace their lost competition, downward pricing pressure on the monopolist's prices will be limited or entirely eliminated. For this same reason, a legal standard for exclusive dealing (or other non-predatory pricing conduct) by a dominant firm that would fail to condemn cost-raising conduct that targets even less efficient competitors would lead to significant false negatives and under-deterrence. ${ }^{52}$

When a monopolist engages in foreclosure against entrants, consumer harm can occur through several mechanisms. ${ }^{53}$ First, the foreclosure can so raise the costs of the potential entrants or constrain their potential sales that it creates prohibitive barriers to entry, in which case the monopolist can maintain its full monopoly price. Second, the foreclosure can raise their costs to a lesser degree, in which case the monopolist may need to reduce its prices somewhat, but by less than if the rivals' costs had not been raised. Third, the foreclosure could restrict the entrants' ability to expand and gain market share, whether or not it raises the entrants' costs of

\footnotetext{
52 Professor Hovenkamp gave the example of a fraudulent patent claim and opined that this standard would be "unreasonably lenient and even perverse. It exonerates the defendant in precisely those circumstances when the conduct is most likely to be unreasonably exclusionary." Herbert Hovenkamp, Exclusion and the Sherman Act, 72 U. CHI. L. REV. 147, 154 (2005); see also John Vickers, Abuse of Market Power, 115 ECON. J. F244 (2005); Steven C. Salop, Exclusionary Conduct, Effect on Consumers, and the Flawed Profit-Sacrifice Standard, 73 ANTITRUST L.J. 311, 328-29 (2006).

53 See generally Krattenmaker \& Salop, supra note 18, at 216, $246-47$.
} 
producing low output levels. ${ }^{54}$ If competitors' outputs are capped by costs of expansion, the monopolist can maintain its supra-competitive pricing while ceding a limited market share to the entrants. Entry by a single small entrant with only a very limited ability to grow is much less threatening to the monopolist's market share, precisely because even if it lowered its price, the entrant would lack the ability profitably to expand its capacity to meet the demand at the new, lower price. In this situation, an accommodating strategy can be a more profitable strategy for the monopolist than significantly reducing its own prices to prevent the entrant from growing. ${ }^{55}$ But, while this strategy of accommodation may be more profitable for the monopolist, it harms consumers by eliminating or reducing price competition.

Exclusive dealing and other exclusionary conduct also can have procompetitive motivations and effects. Buyers may use exclusives in order to induce more price competition among its suppliers. ${ }^{56}$ Exclusives also may provide various other efficiency benefits that have been recognized in the case law and economic analysis. ${ }^{57}$ Some econometric studies suggest the

54 In economic terms, this occurs when the conduct raises the entrant's marginal costs of expansion beyond a limited output level.

55 For the standard economic analysis of the incentives to accommodate the entry of an entrant constrained to remain small, see Drew Fudenberg \& Jean Tirole, The Fat-Cat Effect, the Puppy-Dog Ploy, and the Lean and Hungry Look, 74 AM. ECON. REV. (PAPERS \& PROC.) 361 (1984); Judith R. Gelman \& Steven C. Salop, Judo Economics: Capacity Limitation and Coupon Competition, 14 BELL J. ECON. 315 (1983); Avner Shaked \& John Sutton, Relaxing Price Competition Through Product Differentiation, 49 REv. ECON. STUD. 3 (1982); Louis A. Thomas, Incumbent Firms' Response to Entry: Price, Advertising, and New Product Introduction, 4 INTL. J. IND. ORG. 527 (1999). For application to competitive effects analysis of mergers, see Steven C. Salop, Measuring Ease of Entry, 331 ANTITRUST BULL. 551, 559 n.10 (1986).

56 Richard M. Steuer, Customer-Instigated Exclusive Dealing, 68 ANTITRUST L.J. 239 (2000); Benjamin Klein \& Kevin M. Murphy, Exclusive Dealing Intensifies Competition for Distribution, 75 ANTITRUST L.J. 433 (2008).

57 For examples from the case law, see Standard Oil Co. of Cal. v. United States, 337 U.S. 293, 306-07 (1949); Jefferson Parish Hosp. Dist. No. 2 v. Hyde, 466 U.S. 2, 45 (1984) (O'Connor, J. concurring); see also Jacobson, supra note 18, at 357-60; For a sampling of economics articles that raise possible efficiency claims, see Daniel P. O’Brien \& Greg Shaffer, Nonlinear Supply Contracts, Exclusive Dealing, 
existence of efficiency benefits from vertical restraints in certain industries studied, though the evidence on the competitive effects of exclusive dealing is limited and does not represent a random sample. ${ }^{58}$ It also is mixed in the sense that some studies find evidence of anticompetitive effects. ${ }^{59}$ When there is competition among a number of relatively equal competitors each with its own exclusives, and no coordination, then exclusives also are on balance less likely to cause harm to competition, as opposed to exclusives adopted by a monopolist facing a new entrant. ${ }^{60}$

and Equilibrium Market Foreclosure, 6 J. ECON. \& MGMT. STRATEGY 755 (1997); Howard P. Marvel, Exclusive Dealing, 25 J.L. \& ECON. 1 (1982); Klein, supra note 24.

58 For example, see Francine Lafontaine \& Margaret Slade, Exclusive Contracts and Vertical Restraints: Empirical Evidence and Public Policy, in HANDBOOK OF ANTITRUST ECONOMICS 391 (Paolo Buccirossi, ed., 2008). The particular selection of the studies is not random, but is affected by data availability. In addition, the value of this evidence for setting legal standards to govern the conduct of dominant firms or monopolists is very limited because the selection of studies is affected by the existence of the antitrust laws. Jonathan Baker has explained that restraints that are beneficial in competitive markets can operate differently when used by a dominant firm or a monopolist, and that most of the studies about the consequences of vertical restraints examine firm behavior in settings where anticompetitive conduct would have been deterred by the antitrust laws. As a result, these studies do not provide information about how the likely effects of the practices if the laws were relaxed to permit these practices by dominant firms and monopolists. Jonathan B. Baker, Taking the Error Out of "Error Cost" Analysis: What's Wrong with Antitrust's Right, 80 ANTITRUST L.J. (forthcoming 2014) [hereinafter Error Costs] In addition, even if there are some procompetitive benefits, the likelihood of anticompetitive harms are also higher when exclusives are used by such firms ${ }^{59}$ See sources cited supra note 58. For example, Commissioner Wright's own empirical study of exclusive dealing in beer distribution study found evidence that was consistent with anticompetitive effects. As the authors explain in their working paper, "Our most important result is the finding that the prohibition on exclusive dealing contracts in the beer market is associated with an economically and statistically significant increase in sales. This result provides prima facie evidence [that] exclusive dealing contracts harmed competition by excluding rival brewers." Jonathan Klick \& Joshua D. Wright, The Effects of Vertical Restraints on Output: Evidence from the Beer Industry 20-21 (2008), http://www.utexas.edu/law/wp/wpcontent/uploads/centers/clbe/ wright_effects_of_vertical-restraints.pdf.

59 See sources cited supra note 58. For example, Commissioner Wright's own empirical study of exclusive dealing in beer distribution study found evidence that was consistent with anticompetitive effects. As the authors explain in their working paper, "Our most important result is the finding that the prohibition on exclusive dealing contracts in the beer market is associated with an economically and statistically significant increase in sales. This result provides prima facie evidence [that] exclusive dealing contracts harmed competition by excluding rival brewers." Jonathan Klick \& Joshua D. Wright, The Effects of Vertical Restraints on Output: Evidence from the Beer Industry 20-21 (2008), http://www.utexas.edu/law/wp/wpcontent/uploads/centers/clbe/wright_effects_of_vertical-restraints.pdf.

${ }^{60}$ At the same time, competition for distributors is not a panacea for anticompetitive concerns about exclusive dealing. A monopolist has significant advantages in such competition for distributors because it 
Thus, it is important to analyze the efficiency claims on a case-by-case basis, and take market structure into account, rather than assume their existence and significance.

\section{The Commission's Opinion}

The Commission's McWane case and opinion can be analyzed through the lens of the legal and economic analysis set forth above. McWane comes in the wake of the February 2009 passage of the American Recovery and Reinvestment Act ("ARRA"), which allocated more than $\$ 6$ billion to water infrastructure projects. Waterworks projects funded by the ARRA were required to use domestically manufactured pipefittings. At the time the ARRA was enacted, McWane was the only domestic pipefitting manufacturer, although competitors like Star quickly began seeking their own sources of domestic production. Feeling the competitive pressure from new domestic competitors, McWane allegedly adopted a distribution policy—the Full Support Program—whereby McWane refused to sell to distributors who purchased competitors' pipefittings. The only exceptions to this policy were situations where McWane's fittings were not readily available or where fittings were purchased together with another manufacturer's ductile iron pipe.

Complaint Counsel challenged the Full Support Program under Section 5 of the FTC Act as an exclusive dealing arrangement that served to unlawfully maintain McWane's monopoly position in the domestic pipefitting market. The Commission ruled in Complaint Counsel's

\footnotetext{
is protecting its monopoly power rather than simply attempting to earn a competitive return, as is the entrant. A incumbent monopolist also can negotiate for exclusives before the entrant has time to respond. And where the entrant needs wide distribution, each distributor might accept the monopolist's offer rather than take the risk that the entrant will fail to obtain sufficient distribution from others. See Krattenmaker \& Salop, supra note 18 at 268-77; Steven C. Salop, Economic Analysis of Exclusionary Vertical Conduct:Where Chicago Has Overshot the Mark, How THE CHICAGO SCHOOL OvERSHOT THE MARK: THE EFFECT OF CONSERVATIVE ECONOMIC ANALYSIS ON U.S. ANTITRUST 162, 174-178 (Robert Pitofsky ed., 2008); Ordover et. al., supra note 21. See also sources cited supra note 35.
} 
favor, applying a Sherman Act Section 2 analysis. ${ }^{61}$ It first found that McWane held a

monopoly-level market share in the domestic pipe fittings market, which had substantial barriers

to entry. ${ }^{62}$ Second, it found that McWane feared that entry would force it to reduce prices and

margins. ${ }^{63}$ Third, it found that McWane instituted exclusive dealing with its distributors in

response to entry. ${ }^{64}$ Fourth, it found that McWane's stated rationale for the exclusive dealing

was to deny Star access to its distributors in order to reduce its sales and to force it to use more

costly contract manufacturers. ${ }^{65}$ It also intended to prevent Star from achieving sufficient scale

to make it economical to secure its own lower cost production facility. ${ }^{66}$ Fifth, the Commission

found that once the exclusive dealing was instituted, many major customers stopped placing

${ }^{61}$ McWane at 13 n.7.

62 McWane at 16-17. The Commission found a separate "domestic" fittings market because the ARRA required customers to purchase fittings that were produced domestically except in under certain situations. McWane's market share in the domestic market apparently exceeded 90\%. The Administrative Law Judge found that Star's market share was close to 5 percent for 2010 and almost 10 percent in 2011. Initial Decision at 374 ("After Star entered the Domestic Fittings market, McWane's share of the Domestic Fittings market in 2010 continued to be over 95\%. In 2011, McWane's share of the Domestic Fittings market continued to be over 90\%, while Star's share of the Domestic Fittings market rose from $0 \%$ in 2009 to almost $10 \%$ in 2011. F. 1042-1042.").

McWane Appeal Br. at 9. Sigma, the only other significant domestic fittings supplier, sourced its domestic fittings exclusively from McWane under an agreement that allowed McWane to cut off Sigma if it priced its fittings at less than 98 percent of McWane's published pricing. McWane at 12.

63 See id. at 8 (McWane "worried that entry by Star and Sigma would threaten to undermine its domestic fittings prices."); id. at 30-31 ("McWane considered the impact of lowering its domestic fitting[] pricing 'to defend [its] near $100 \%$ share position,' but ultimately determined that lowering pricing would hurt margins." (second alteration in original) (citation omitted)). Sigma apparently responded to McWane's conduct by becoming a McWane distributor. See id. at 11-12.

${ }^{64}$ McWane's policy allowed for limited exceptions for items McWane was unable to supply or that were purchased with another manufacturer's ductile iron pipe. $I d$. at 9.

65 See id. at 20 ("McWane's Full Support Program is an exclusive dealing policy by its terms, operation, and intent. McWane designed and implemented the program to deny Star and other potential competitors access to distributors and thereby impede their effective entry into the domestic fittings market in order to maintain its monopoly."); $i d$. at 26.

${ }^{66}$ See id. at 20-21, 25 ("McWane's announcement of its exclusive dealing policy in September [2009] and its impact on Star's sales prompted Star to rethink its strategy of acquiring a domestic foundry."). 
orders with Star, reducing its anticipated sales. ${ }^{67}$ Sixth, it found that during this period of exclusive dealing, Star's sales were limited to a low level and McWane maintained monopolylevel prices and market share. ${ }^{6}$ Seventh, it found that during this period of exclusive dealing, McWane did not reduce its prices, but actually increased them. ${ }^{69}$ Eighth, it found that Star did not exit, but it also did not build its own lower cost facility. ${ }^{70}$ Ninth, the Commission found that McWane failed to show any cognizable efficiency rationale for the exclusive dealing. ${ }^{71}$

Based on these findings, the Commission concluded that McWane's conduct permitted it to maintain its monopoly position:

With few exceptions, McWane's program forced its distributors to carry McWane domestic fittings exclusively. McWane thus deprived its rivals, mainly Star, of distribution sufficient to achieve efficient scale, thereby raising costs and slowing or preventing effective entry. The result harmed competition by increasing barriers to entry and allowing McWane to maintain its monopoly position, which prevented meaningful price competition and deprived consumers of the ability to choose among the products, terms of sale, and services of varying suppliers of domestic fittings. ${ }^{72}$

McWane's conduct involves both input and customer foreclosure. McWane

foreclosed Star from access to major distributors, which were found to be critical to effective

67 See id. at 23-24.

68 See id. at 27-28. The Commission says that the Full Support program enabled McWane to keep prices high. See id. at 28 ("By adopting the program, McWane was able to ensure that prices and gross profits for domestic fittings remained high.") The Commission then goes on to say "In fact . . McWane raised domestic fittings prices and increased gross profits [during 2009 and 2010]." See id. at 28. The Administrative Law Judge found that Star's market share was close to 5 percent for 2010 and almost 10 percent in 2011. Initial Decision at 374.

${ }^{71}$ See id. at 30-32 (rejecting proffered efficiencies of preserving sales volume and incentivizing customer loyalty to full product line). 
competition. ${ }^{73}$ As a result, Star would be burdened with higher costs of expansion that would constrain its output to such a low level that McWane would not be forced to engage in significant price competition, but could simply cede a low market share to Star.

The Commission's conclusion follows the modern approach to exclusive dealing with respect to both the economics and the law. Adopting the rule of reason standard used by the circuit courts in Dentsply and Microsoft, the Commission recognized that exclusive dealing may substantially harm competition by impairing rivals' access to the downstream markets and limiting the scale of their output, even if it did not completely exclude rivals from the market. McWane was a monopolist facing entry by a single independent rival. McWane recognized that if Star emerged as a "legitimate competitor,"74 "our distributors will continually pressure us to 'do something' (lower prices). If [Star] stay[s] in business, we will always see downward pressure in the future."75 McWane's exclusive dealing foreclosed Star "from accessing a substantial share of distributors.,"76 The loss of this access raised Star's distribution costs and limited its sales. ${ }^{77}$ While Star was not totally foreclosed from the market, the exclusivity raised its costs of distribution, reduced its sales and limited its ability to expand efficiently, thereby reducing its ability to place competitive pressure on McWane. ${ }^{78}$

73 As stated by the Commission, "A domestic fittings entrant is unable to compete effectively without access to distributors." McWane at 22.

${ }^{74}$ Id. at 31 (quoting Complaint Counsel's CX00102 at 002 (describing the "'biggest risk factor" as the '[e]rosion of domestic pricing if Star emerges as a legitimate competitor'").

75 Initial Decision at 417 (alterations in original) (citation omitted).

76 McWane at 23.

77 See McWane at 25, 27-28.

78 Id. at 22 ("McWane [] deprived its rivals, mainly Star, of distribution sufficient to achieve sufficient scale, thereby raising costs and slowing or preventing effective entry."); $i d$. at 31 ("[T] he sales gained for production by McWane's exclusive-dealing arrangement were sales taken from Star by virtue of the increased costs imposed by the Full Support Program."). 
The lower sales also prevented Star from reaching the scale necessary to justify investing in its own foundry where its costs would have been lower, enabling it to more aggressively compete with McWane. ${ }^{79}$ The Commission refers to the various causes of higher costs from dealing with independent foundries, including lower batch sizes. ${ }^{80}$ At the same time, the only other entrant, Sigma, chose to become a McWane distributor, rather than arranging for its own independent pipefitting production. ${ }^{81}$

As a result, Star's entry did not cause McWane's prices to fall below the monopoly level. ${ }^{82}$ With no other competitors to challenge it and cause downward pressure on prices, McWane was able to maintain a monopoly price level. The adverse impact on Star's ability to compete and the resulting impact on competition were rationally anticipated by McWane. ${ }^{83}$ When the Commission analyzed the evidence regarding McWane's claimed efficiency rationale, that rationale also was rejected. Thus, if these factual findings are valid, then there would be sufficient evidence to find harm to competition. ${ }^{84}$

79 McWane at 25, 27.

80 McWane at 25.

81 McWane at 11-12.

${ }^{82} I d$. at 18 (finding McWane's "ability to control prices in the domestic fittings market . . . direct evidence of McWane's monopoly power.").

${ }^{83}$ Id. at 8-9. This anticompetitive intent evidence is consistent with the finding of anticompetitive effects on prices and consumers.

84 The Commission's approach also fits comfortably into the 3 prongs of the standard "raising rivals' costs" framework for analyzing exclusive dealing and other exclusionary conduct. The exclusive dealing satisfied the upstream "raising rivals' cost" ("harm to competitors") prong because it raised Star's costs of distribution and production, eliminated competition from Sigma and raised barriers to entry and expansion by restricting Star's access to the major distributors. The exclusive dealing satisfied the downstream "power over price" ("harm to competition") prong because the higher costs and lower output inflicted on the only independent entrant would prevent market prices from falling and thereby permit McWane profitably to maintain its monopoly level prices without a substantial loss in market share, thereby harming consumers and competition. As for the "efficiency" prong, McWane failed to trump the finding of harm to competition by showing cognizable efficiency benefits. See Krattenmaker \& Salop, supra note 18 . 


\section{Commissioner Wright's Dissent}

Commissioner Wright found the evidence insufficient to conclude that McWane violated antitrust law. Commissioner Wright did not think this was even a close case, stating that Complaint Counsel "totally fails" to establish harm to competition under his legal standard. ${ }^{85}$ Commissioner Wright did not disagree with the Commission on a number of relevant issues. He "agree[d] with the Commission's conclusion that in the domestic fittings industry, distributors are a key distribution channel and that a supplier cannot compete effectively without having some access to distributors." 86 He concluded that there was "ample record evidence demonstrating that the Full Support Program harmed McWane's rival Star," presumably by excluding it from using certain major distributors. ${ }^{87}$ He also assumed (but did not find) that McWane was a monopolist. ${ }^{88}$ Nor did he question the evidence regarding McWane's stated anticompetitive purpose to use its exclusive dealing to foreclose Star and reduce Star's impact on competition. While Commissioner Wright suggested that full-line forcing logically might lead to procompetitive effects as a matter of economic theory, he did not analyze the evidence relevant to McWane's specific efficiency claims and did not conclude that the claims were supported by the evidence. ${ }^{89}$ In interpreting the economic evidence, Commissioner Wright endorsed the use

\footnotetext{
${ }^{85}$ Dissent at 4-6.

${ }^{86} \quad I d$. at 33 n. 40 .

87 Id. at 4.

${ }^{88} \quad I d$. at 7 n. 14 .

${ }^{89}$ Id. at 48-49 n.55. The Commission rejected McWane's claimed efficiencies. See McWane at 30-32.
} 
of the RRC paradigm for exclusive dealing analysis ${ }^{90}$ and explicitly did not adopt a total foreclosure standard. ${ }^{91}$

However, Commissioner Wright had other substantial disagreements with the Commission on key issues of economics and law. In conflict with the Commission and modern economic analysis of anticompetitive exclusion, Commissioner Wright limited his economic analysis of the mechanisms by which exclusion may harm competition solely to whether the exclusive dealing prevented Star from reaching MES. Commissioner Wright also adopted a new and fundamentally different legal standard to govern interbrand exclusionary conduct by a monopolist. His standard placed a heightened burden of production and proof on the plaintiff to demonstrate "clear evidence" of harm to competition before shifting the burden to defendant to show specific procompetitive efficiencies. ${ }^{92}$ His "clear evidence" standard requires showing more than "actual or probable" anticompetitive effect by a "preponderance of the evidence" and appears to require something much closer to certainty.

In applying his skeptical "clear evidence" standard to interpret the facts, Commissioner Wright minimized the direct evidence of price effects that was found by the Commission by

90 Dissent at 10-12. He also endorses this approach in his scholarly work. Wright, Naïve Foreclosure, supra note 24, at 1166.

91 Dissent at 35 n.42 ("[T] $]$ he mere fact that the foreclosure rate need not be $100 \%$ to violate the law does not obviate the need to connect the identified foreclosure rate with the defendant's ability to maintain monopoly power."). He stated this view more broadly in Nä̈ve Foreclosure, explaining that it is necessary to show that the exclusives "substantially foreclose rivals from a critical input for a period sufficient to decrease market output and raise market prices." Wright, Nä̈ve Foreclosure, supra note 24, at 1163-64. However, the analysis in his statement takes a narrow approach to what constitutes substantial foreclosure.

92 To avoid confusion, we refer to both the burden of production and the burden of proof. As explained in Baker Hughes, the distinction between the defendant's burden of production and the ultimate burden of persuasion is "always an elusive distinction in practice." United States v. Baker Hughes Inc., 908 F.2d 981, 991 (D.C. Cir. 1990). 
disputing certain details in the evidence. For example, the Commission found direct evidence of price effects by comparing the profitability of domestic versus non-domestic fittings, and by noting the failure of McWane to reduce prices in the face of Star's entry, evidence that Commissioner Wright appeared to ignore. Commissioner Wright also did not place weight on the fact that Star's market share almost doubled in the period after he found that the exclusives ended. Commissioner Wright also did not take into account other relevant evidence that could help to support an inference of increased likelihood of harm to competition. This included the fact that McWane was a monopolist, that distributors were critical in this industry, that McWane instituted its exclusive dealing program with the avowed purpose of hobbling entrants, and that the Commission found (but he did not analyze) that there were no cognizable efficiency benefits.

In our view, Commissioner Wright's legal and economic approach significantly departed from the prevailing economic analysis and case law on exclusive dealing. The economics of exclusion and the case law recognize a variety of mechanisms by which exclusive dealing can harm competition, not simply whether the entrant is prevented from reaching MES. The empirical evidence also does not justify a presumption that exclusive dealing by a monopolist is highly likely to be procompetitive. In contrast to the case law, Commissioner Wright's proposed legal standard would impose higher burdens of production and proof on the plaintiff to demonstrate harm to competition before shifting the burden to the defendant to show valid cognizable efficiency benefits. Adoption of this standard would lead to excessive false negatives, under-enforcement and under-deterrence of anticompetitive exclusive dealing by monopolists.

We next discuss these issues in detail. 


\section{A. Marginalization of Relevant Economic Theory and Evidence}

Commissioner Wright concluded that Complaint Counsel did not establish an analytical link between foreclosure and harm to competition, and thus failed to meet its burden of proof. ${ }^{93}$ But, in reaching his conclusion, Commissioner Wright's economic analysis unduly bounded the relevant economic theory of exclusion by limiting his analysis of how exclusion may harm competition. Limited in this way, Commissioner Wright's analysis was unable to properly evaluate "the ultimate substantive question in antitrust analysis: which model best explains the business conduct at issue in light of the available data." 94 Instead, his narrowed economic analysis would severely limit the ability to prove harm to competition, even where there is consumer harm.

Commissioner Wright's statement recognized that, "Modern economic theory teaches that exclusive contracts can harm competition when a monopolist uses exclusivity provisions in contracts with suppliers or distributors to raise the cost its rival faces in buying supply or contracting with distributors." 95 However, after making this general statement that endorsed the “raising rivals' cost" economic paradigm for analyzing anticompetitive exclusion, ${ }^{96}$ Commissioner Wright's specific application of this economic analysis to exclusive dealing was narrow and did not cover all the ways exclusive dealing or other exclusionary conduct could limit its rival's ability to compete and permit the monopolist to maintain monopoly prices.

93 See Dissent at 35 ("[N]either Complaint Counsel nor the Commission provides an analytical link between Complaint Counsel's foreclosure analysis and competitive harm.").

94 Joshua D. Wright, Abandoning Antitrust's Chicago Obsession: The Case for Evidence-Based Antitrust, 78 ANTITRUST L.J. 241, 242 (2012) [hereinafter Chicago Obsession].

95 Dissent at 10.

96 See also Nä̈ve Foreclosure, supra note 24, at 1163. 
Commissioner Wright took a much more limited view of the effects of McWane's

conduct on Star than did the Commission. According to Commissioner Wright:

[E]xclusive dealing cannot result in the acquisition or maintenance of market power and harm competition unless the contracts foreclose a rival from access to a critical input necessary to achieve minimum efficient scale (MES). In other words, a coherent theory of exclusion involving exclusive dealing contracts requires an analytical link between the contracts and the MES of production. ${ }^{97}$

In limiting his economic analysis only to the MES issue, Commissioner Wright departed

from established economic theory by ignoring the probable impact of a rival's higher distribution costs on its ability to compete and expand, whether or not it is able to reach the MES level of output. ${ }^{98}$ The Commission followed the modern approach to exclusion, stating that

97 Dissent at 10-11 (footnote omitted). Commissioner Wright stated the customer foreclosure theory as follows: "Absent these contracts, the rival (or entrant) could cover its fixed costs by attracting a large enough mass of suppliers or distributors." Id. However, he does not refer to the impact of the foreclosure on raising the rival's costs at MES, or the impact of restricting the output of viable competitors aside from the issue of reaching MES.

98 Commissioner Wright suggested that the concept of “'raising rivals' costs' underlying modern anticompetitive theories of exclusion generally requires input foreclosure sufficient to deprive a rival from achieving minimum efficient scale." Dissent at 11 n.15 (emphasis added). See also Nä̈ve Foreclosure, supra note 24, at 1166. Commissioner Wright also cites Klein, supra note 24, and Krattenmaker \& Salop, supra note 18, at 247, for his claim. However, Commissioner Wright's characterization was not consistent with the analysis in Krattenmaker and Salop's article that he cites. Krattenmaker and Salop focused on all increased costs inflicted on rivals, not just those arising from a failure to reach MES. In fact, if rivals are deprived access to the most cost-efficient inputs or have to pay more for them, the rivals' costs will be higher. These higher costs can occur even the rival achieves the MES level of output. As a result of the higher costs or reduced output and inability to expand at low cost, those rivals will provide less of a competitive constraint on the excluding monopolist, which can permit the monopolist to gain power over price to maintain its monopoly prices.

Commissioner Wright drew a quotation from Krattenmaker and Salop that “"[E]xcluded rivals no longer produce at minimum cost if the exclusionary rights agreement compels them to substitute less efficient inputs." Dissent at 11 n.15 (alteration in original); see also Nä̈ve Foreclosure, supra note 24, at 1166 n.20. However, this quotation does not even refer specifically to MES. Instead, the quotation refers any cost increase that raises rivals' costs by leading them to substitute to "less efficient" inputs. Less efficient inputs would include the rival being restricted by exclusive dealing to directly distributing its products instead of using more cost-efficient distributors in the market. It also would include the rival being compelled to use a more expensive or less productive distribution system or other input, instead of a more cost-efficient one that is foreclosed by the exclusive dealing of a dominant firm or monopolist. These 
anticompetitive effects "can occur even aside from the issue of whether the rival is able to reach the MES level at which its average costs bottom out. Exclusive dealing can be anticompetitive, therefore, if it facilitates the exercise of market power by either impairing a rival's ability to achieve the scale necessary to become efficient, or if it makes a rival less efficient by depriving it of 'efficient access to the downstream market.",99 If the only independent competitor remains viable, but the foreclosure limits its output sufficiently, then the monopolist will have less or no need to reduce its prices to compete, and instead will be able to maintain monopoly prices while ceding a small market share to the competitor. This does not necessary involve the rival's output being restricted below its MES. Instead, it can involve a higher cost at the relevant output level (whether MES output or other output level). ${ }^{100}$

Commissioner Wright's statement referred to the scale of production necessary for Star building its own foundry. ${ }^{101}$ But his analysis failed to fully trace out the entire causal chain and probable impact of the fact that access to distributors was required for a supplier like Star to "compete effectively." If Star had higher distribution costs because it lacked access to sufficient efficient distributors, or if Star's output and ability to expand were constrained by lacking access to these distributors, then Star would place less competitive price pressure on McWane, even if

conditions are much more general than whether the restraint prevents the rival from reaching a particular scale of output such as the MES.

${ }^{99}$ McWane at 19 (citing Herbert Hovenkamp, XI Antitrust Law II 1802b, at 7476) (italics added).

${ }^{100}$ See supra, Section II.

${ }^{101}$ See Dissent at 29-30. This required scale of production is more of a MVS concept than a MES concept. This MVS would be the production level for which the investment in a new foundry would be justified, given prices. It would necessarily be equal to the MES (i.e., the level of production where average costs would be minimized). See supra note 25. When Commissioner Wright referred to MES, it is possible that he really means MVS. But, MVS is not necessarily the same level as MES, particularly in a monopolized market. Such confusion would not be unique. For example, see Crane \& Miralles, supra note 26 at 608 (incorrectly defining MVS as equal to the percentage of the market necessary for a rival to minimize its average costs, that is, as MES). 
Star had achieved MES. ${ }^{102}$ As a result, McWane would be able to maintain monopoly prices, despite Star remaining viable, just as McWane had intended. ${ }^{103}$

\section{B. Commissioner Wright's "Clear Evidence" Standard}

Commissioner Wright's legal standard requires the plaintiff to show "clear evidence" of harm to competition before shifting the burden to the defendant to show procompetitive efficiencies. ${ }^{104}$ This standard rejects the usual "preponderance of the evidence" standard for showing probable anticompetitive effects. ${ }^{105}$ It is not enough to produce evidence of "probable (not certain)" anticompetitive effect. ${ }^{106}$

This legal standard can be compared to the rebuttable presumption of harm standard in Philadelphia National Bank. In that case, the Supreme Court held that mergers that lead to high market shares in highly concentrated markets were presumed anticompetitive. ${ }^{107}$ This

102 These effects would occur irrespective of whether Star's output achieved MES. To illustrate with a numerical example, suppose that a firm reaches minimum efficient scale at an output of 100 units and its marginal cost at this MES output level is $\$ 10$ per unit. If exclusionary conduct raises its costs by $50 \%$ at every output level, then the firm's marginal costs would be $\$ 15$, even if it reached MES. In addition, with marginal cost of $\$ 15$, it might be most profitable for it to sell fewer than 100 units, even though it would be feasible to expand its production beyond this output level.

${ }^{103}$ This outcome could occur even if Star never had any expectation of building its own foundry because it still would have higher distribution costs and lower output as a result of the exclusive dealing, which would reduce its ability to constrain McWane's prices. Loss of access to distributors would reduce its output and that lower output also could lead to higher production costs from smaller batch sizes and less bargaining power with independent foundries, as well as higher distribution costs. Similarly, even if its production costs would not be higher, its distribution costs would be. And, even if Star did eventually build a lower cost foundry, the exclusivity would have delayed its investment and it still likely would have higher distribution costs from the exclusivity.

${ }^{104}$ Dissent at 18.

${ }^{105}$ Commissioner Wright stated that Complaint Counsel was not meeting its burden to show "by a preponderance of the evidence" that McWane's program harmed competition. Dissent at 1 . However, his standard actually mandates a higher "clear evidence" standard.

106 See Dissent at 18 (quoting Roland Machinery Co. v. Dresser Indus., 749 F.2d 380, 394 (7th Cir. 1984).

107 As the Court stated, "[A] merger which produces a firm controlling an undue percentage share of the relevant market, and results in a significant increase in the concentration of firms in that market is so 
presumption, the Court said, could only be rebutted by "clearly showing" that the merger was not anticompetitive. ${ }^{108}$ Commissioner Wright's proposed standard essentially inverts the Philadelphia National Bank "clear showing" standard. His standard would be consistent with the position that exclusive dealing by a monopolist should be presumed so inherently likely to be procompetitive that the presumption can only be rebutted and the conduct enjoined by "clear evidence" of anticompetitive effect. Moreover, as Commissioner Wright's analysis demonstrated, only certain findings even qualify to be considered "clear evidence."

Commissioner Wright defended his standard on the grounds that vertical restraints law and economics have changed dramatically since Sylvania. As he explained, "it is well-accepted that the economic learning accumulated since GTE Sylvania has taught that such [vertical] restraints ... rarely harm competition and often benefit consumers." ${ }^{109}$ He then coupled this foundation to the burden-shifting framework set out in Microsoft, whereby the plaintiff must show evidence of harm to competition before shifting the burden to the defendant to show evidence of procompetitive efficiencies.

In our view, there is no economic basis for this strong presumption of procompetitive effects from exclusive dealing by a monopolist or the associated "clear evidence" standard. As discussed above, exclusive dealing can raise barriers to entry and expansion in highly profitable

inherently likely to lessen competition substantially that it must be enjoined in the absence of evidence clearly showing that the merger is not likely to have such anticompetitive effects." United States v. Phila. Nat'l Bank, 374 U.S. 321, 363 (1963).

${ }^{108}$ Over time, the Philadelphia National Bank presumption has been weakened by a recognition that this presumption places too high a burden on the merging parties. United States v. Baker Hughes Inc., 908 F.2d 981, 991 (1990). The court embraced a sliding scale approach, whereby " $[\mathrm{t}] \mathrm{he}$ more compelling the prima facie case, the more evidence the defendant must present to rebut it successfully." Id.

${ }^{109}$ Dissent at 2-3. 
ways. ${ }^{110}$ Economic analysis has identified a number of reasons why entrants and small competitors are unlikely to be able to prevent their foreclosure by competing for non-exclusive access. ${ }^{111}$ The available empirical evidence also does not support Commissioner Wright's strong presumption of procompetitive effects for exclusive dealing by a monopolist. ${ }^{12}$ Because exclusive dealing by a monopolist against all (or the only independent) entrants does not provide a compelling case for procompetitive effects, the burden placed on the plaintiff's prima facie case should not be overly stringent.

Commissioner Wright's proposed standard goes far beyond both the case law and standards proposed by other commentators. In Aspen Skiing, the Court held that conduct violates Section 2 if it "unnecessarily excludes" or is "unnecessarily restrictive." "113 As stated by the Court, "it is relevant to consider its impact on consumers and whether it has impaired competition in an unnecessarily restrictive way. If a firm has been 'attempting to exclude rivals on some basis other than efficiency,' it is fair to characterize its behavior as predatory." 114 In light of the Commission's rejection of McWane's efficiency rationale and the harm to consumers

\footnotetext{
${ }^{110}$ See infra, Section II.
}

${ }^{111}$ See the sources cited supra note 61.

${ }^{112}$ As discussed above, supra notes 59-60, the econometric evidence is limited and mixed. Commissioner Wright's 2008 working paper characterizes the evidence on the competitive effects of exclusive dealing as "scarce," though that 6-year old article may no longer reflect his views of the empirical evidence. Klick \& Wright, supra note 60, at 15. In addition, as Professor Baker has explained, the evidence is biased because it does not take into account that anticompetitive use of exclusive dealing by monopolists is deterred by the antitrust laws. Error Costs, supra note 59, at 23. Nor do the studies focus on exclusive dealing by a monopolist targeted against the only entrant.

${ }^{113}$ Aspen Skiing Co. v. Aspen Highlands Skiing Corp., 472 U.S. 585, 605, \& n.32 (1985) (quoting 3 PHILLIP AREEDA \& DONALD F. TURNER, ANTITRUST LAW 78 (1978)).

${ }^{114}$ Id. at 605 (quoting BORK, supra note 16, at 138). 
found by the Commission, McWane's conduct seemingly would be condemned under that standard. $^{115}$

The Microsoft court used a Section 2 balancing standard that it noted is similar to the Section 1 rule of reason balancing standard. The overarching standard is that the plaintiff "must demonstrate that the anticompetitive harm of the conduct outweighs the procompetitive benefit."116 The Microsoft court also suggests a burden-shifting decision structure. But neither the Section 1 rule of reason nor the Microsoft court ever suggests that exclusive dealing by a monopolist is so inherently likely to be procompetitive or that there should be a "clear evidence" burden placed on the plaintiff.

The Microsoft court explicitly did not require the type of "direct evidence" mandated by Commissioner Wright. The court observed that, it could find no §2 case "standing for the proposition ... that plaintiffs must present direct proof that a defendant's continued monopoly power is precisely attributable to its anticompetitive conduct." ${ }^{117}$ The court further observed that “[t]o require that $\$ 2$ liability turn on a plaintiff”s ability or inability to reconstruct the hypothetical marketplace absent a defendant's anticompetitive conduct would only encourage monopolists to take more and earlier anticompetitive action." ${ }^{118}$ Yet, Commissioner Wright asked for just that type of evidence."119

115 The Aspen Skiing Court stressed the lack of a legitimate business justification, saying, "Perhaps most significant, however, is the evidence relating to Ski Co. itself, for Ski Co. did not persuade the jury that its conduct was justified by any normal business purpose." $I d$. at 608 .

${ }^{116}$ United States v. Microsoft Corp., 253 F.3d 34, 59 (D.C. Cir. 2001).

${ }^{117}$ Id. at 79.

${ }^{118} I d$.

${ }^{119}$ See Dissent at 5 n.10 ("Such direct evidence of an impact upon price or output might be, for example, a comparison of actual prices and industry output during the relevant time period against an estimate of the 
Professor Jonathan Baker's interpretation of the Microsoft burden-shifting approach is closer to the economic analysis of anticompetitive exclusion by a monopolist. According to Professor Baker, "proof that the monopolist has foreclosed all actual or potential rivals would undoubtedly be sufficient to establish plaintiff's prima facie case." ${ }^{20}$ This makes economic sense because effective foreclosure (e.g., leading to higher costs or barriers to entry and expansion) necessarily would have reduced the competitive downward pricing pressure faced by the monopolist.

Commissioner Wright's proposed standard has gone far beyond any of these standards. Under his standard, even if there were no cognizable, procompetitive justifications or efficiency benefits for the conduct, the defendant would still prevail, unless the plaintiff can show competitive harm with "clear evidence."121 While this standard is not per se legality, it skates close to that standard. ${ }^{122}$

Commissioner Wright's statement explains that Sylvania and subsequent cases replaced per se illegality for intrabrand vertical restraints in favor of the rule of reason. But, his proposed legal standard is not the usual rule of reason. The rule of reason standard would find liability if the likely competitive harm were found to outweigh the likely competitive benefits by a

prices and output that would have occurred during the relevant time period had McWane not engaged in the challenged conduct."). In addition, as discussed below, infra Section IV.D, Commissioner Wright did not properly account for all the direct evidence of price effects.

${ }^{120}$ Baker, Core Concern, supra note 20, at 549.

${ }^{121}$ See Dissent at 18.

${ }^{122}$ Commissioner Wright minimized the direct evidence found by the Commission that monopoly prices were maintained during the period of exclusive dealing, as discussed infra, Section IV.D. He also did not draw any inference of an increased likelihood of harm to competition from the fact that defendant was a monopolist, or that the defendant's explicit purpose was to hobble the entrant, as discussed infra, Section IV.C. He also did not find it relevant to evaluate the evidence produced at trial on the defendant's lack of efficiency justification. $I d$. 
preponderance of the evidence. The Sylvania Court did not apply Commissioner Wright's strong presumption of procompetitive effects and then require the plaintiff to produce "clear evidence" of harm to competition before shifting the burden back to the defendant to produce evidence of efficiencies. The Court simply refused to apply a conclusive presumption of anticompetitive harm embedded in the per se rule but applied the usual rule of reason standard instead. ${ }^{123}$ The rule of reason also does not reject inferences of harm to be drawn from a combination of structural evidence, indirect evidence and economic theory. In the actual Sylvania case, the presence of structural evidence and economic theory strongly inferred that efficiency benefits were likely and competitive harms were unlikely.

Commissioner Wright's proposed standard also does not distinguish among types of vertical restraints and does not take into account the impact of market structure on the likelihood of anticompetitive harms. ${ }^{124}$ Sylvania involved an intrabrand restraint by a small firm that lacked market power. ${ }^{125}$ Sylvania also had a cognizable efficiency justification. Yet, Commissioner Wright applied his far more permissive standard to an interbrand restraint adopted by a monopolist that lacked a legitimate efficiency justification for its conduct. As a result, the

${ }^{123}$ See Cont'l T.V., Inc. v. GTE Sylvania, Inc., 433 U.S. 36, 58-59 (1977).

${ }^{124}$ Commissioner Wright explained that economic analysis and some empirical studies since Sylvania have supported the view that vertical restraints often have efficiency benefits. See Dissent at 2-3. However, the economics literature does not justify per se legality or Commissioner Wright's excessive burden of proof. The studies are mixed, as discussed supra note 59. Market structure matters. As explained by Professor Baker, practices that may be beneficial in competitive markets can be harmful in monopoly markets. Error Costs, supra note 59. Empirical studies of vertical restraints in competitive markets do not reliably predict the likely effects of the same practices by monopolists. This is also why it is useful to analyze the firm's purpose in adopting the restraint. In addition, if there are no cognizable efficiencies, then the likely effect on consumers and competition also is more likely to be harmful.

${ }^{125}$ Sylvania's market share was "approximately 5\%." GTE Sylvania, 433 U.S. at 38. Jefferson Parish involved a hospital with just $30 \%$ of the market. See Jefferson Parish Hosp. Dist. No. 2 v. Hyde, 466 U.S. 2, 7 (1984). 
policy considerations underlying Sylvania would not provide an adequate justification for Commissioner Wright's standard.

Commissioner Wright also defended his standard as having been used by the FTC in its 1982 Beltone decision. ${ }^{126}$ However, the standards clearly are not identical. Beltone's standard required "reasonably clear evidence of probable overall competitive harm."127 Commissioner Wright's standard would significantly raise the burden on the plaintiff by deleting the qualifiers "reasonably," "probable" and "overall" to arrive at a more stringent burden of "clear evidence of anticompetitive effect." ${ }^{128}$ His standard also would require that clear evidence of anticompetitive harm be shown, even before shifting the burden to the defendant to show efficiency benefits. ${ }^{129}$ In Beltone, the analysis of efficiency benefits was relevant to determining the "overall" effect of the conduct. ${ }^{130}$

Moreover, there are several relevant factual differences between the two matters. First, Beltone was not a monopolist, whereas the Commission found (and Commissioner Wright assumed) that McWane was a monopolist. ${ }^{131}$ Second, the degree of foreclosure in Beltone was

${ }^{126}$ Beltone Elecs. Corp., 100 F.T.C. 68 (1982).

${ }^{127}$ Dissent at 17 (quoting Beltone, 100 F.T.C. at 209).

${ }^{128}$ Dissent at 18.

${ }^{129}$ See Dissent at $48-49$ \& n.55.

${ }^{130}$ Beltone, 100 F.T.C. at 95 (" $[\mathrm{A}]$ rule of reason analysis requires balancing of the competitive merits and demerits of a particular restraint, a process that implicitly requires some consideration of the justifications advanced in support of the restraint."). The Commission also noted that its assessment involved the "overall reasonableness of the challenged restraint." Id.

${ }^{131}$ Beltone, 100 F.T.C. at 89 (Beltone had a market share of $18.8 \%$ expressed in units and $20.7 \%$ expressed in dollars of the hearing aid market). 
limited only to a modest portion of the hearing aid market. ${ }^{132}$ Third, Beltone asserted efficiency rationales for its conduct that the Commission accepted. ${ }^{133}$

We agree with Commissioner Wright that antitrust analysis of exclusion should be based on evidence of likely competitive effects. ${ }^{134}$ But, the combination of Commissioner Wright's "clear evidence" standard, the limited scope of his economic analysis of how exclusives can raise rivals' costs and limit their output, and his failure to consider structural and other evidence, is not an appropriate effects-based standard. The case law generally requires the plaintiff to prove "actual or probable" anticompetitive effects." 135 His proposed standard goes further by essentially removing the term "probable and raising the burden for establishing "actual" effects, including eliminating a role for reasonable inference. The inevitable result of that higher burden

${ }^{132} I d$. at 96 ("“A]s the record reveals, the foreclosure in this case affects only about 7 or $8 \%$ of the dealers, or about $16 \%$ of sales").

${ }^{133}$ In contrast, McWane's justifications were rejected by the Commission, yet Commissioner Wright did not even find it relevant to evaluate McWane's efficiency evidence. In his view, the evidence of harm to competition was so insufficient that McWane's conduct would pass muster even absent efficiency benefits.

${ }^{134}$ See generally Chicago Obsession, supra note 96; Krattenmaker \& Salop, supra note 18; Salop, supra note 52 .

${ }^{135}$ E.g., Tampa Elec. Co. v. Nashville Coal Co., 365 U.S. 320, 329 (1961) ("probable effect of the contract on the relevant area of effective competition"); Standard Oil Co. of Cal. v. United States, 337 U.S. 293, 299 (1949) (" [I]t must also be demonstrated that competitive activity has actually diminished or probably will diminish.”); Spectrum Sports, Inc. v. McQuillan, 506 U.S. 447, 459 (1993) (“[D]angerous probability of achieving monopoly power."); Beltone Elecs., 100 F.T.C. at 209 (requiring "reasonably clear evidence of probable overall competitive harm"); United States v. Microsoft, 253 F.3d 34, 69 (2001) (“[A]n exclusive contract does not violate the Clayton Act unless its probable effect is to "foreclose competition . ...'”) (quoting Tampa Elec., 365 U.S. at 327); ZF Meritor, LLC v. Eaton Corp., 696 F.3d 254, 271 (3d Cir. 2012) ("[A]n exclusive dealing arrangement is unlawful only if the 'probable effect' of the arrangement is to substantially lessen competition ...." (citation omitted)), cert. denied, 133 S. Ct. 2025 (2013); Omega Envt'l, Inc. v. Gilbarco, Inc., 127 F.3d 1157, 1162 (9th Cir. 1997) ("Only those arrangements whose 'probable' effect is to 'foreclose competition ..., violate Section 3.'” (citation omitted)). 
of proof would be excessive false negatives and under-deterrence of anticompetitive exclusion. ${ }^{136}$

\section{Failure to Credit Inferential Evidence}

In imposing this heightened burden, Commissioner Wright's proposed legal standard also does not take into account certain reasonable inferences that can be drawn from a variety of evidence. His economic analysis and legal standard in this case failed to credit relevant evidence that could help to infer an increased likelihood of harm to competition.

\section{Relevant Structural Evidence}

Commissioner Wright's proposed legal standard and economic analysis failed to take into account relevant structural economic evidence that could help an economist or court to draw an inference of harm to competition. Commissioner Wright assumed that McWane was a monopolist, but did not treat this fact as a reason to be more concerned about the conduct. ${ }^{137}$ Nor did he appear to place any weight on the fact that Star was the only independent entrant or that access to distributors was essential to efficiency. The case law does not take such a rigid approach.

\footnotetext{
${ }^{136}$ See generally Louis Kaplow, Burden of Proof, 121 YALE L.J. 738, 758-62 (2012) (discussing how raising and lowering the evidence threshold required to convict impacts the incidence of false positives and negatives). False negatives generally are as serious a concern as false positives. As explained by Professor Baker, the arguments that false negatives raise less serious concerns than false positives do not stand up to the logic of current antitrust law. See Error Costs, supra note 59. Both types of errors also contribute to under-deterrence by reducing the incentives to satisfy the standard, relative to the case in which there are no errors. With both types of errors, there is a smaller increase in the likelihood of being convicted and penalized when an individual actually violates the legal standard, compared to when the individual actually satisfies the standard. See Richard A. Posner, An Economic Approach to the Law of Evidence, 51 STAN. L. REV. 1477, 1484 (1999). For a simple technical example, see Henrik Lando, Does Wrongful Conviction Lower Deterrence?, 35 J. LEGAL STUD. 327, 329-30 (2006).
}

${ }^{137}$ Dissent. at 7 n.14 (stating that there is no need to decide whether McWane was a monopolist). 
If an excluding firm's exclusive dealing effectively raises the cost of a rival or restricts its output, the resulting harm to a competitor alone does not establish by itself that there is harm to competition and consumers. The conduct may also create cognizable efficiency benefits that increase competition. ${ }^{138}$ And, even when there are no efficiency benefits, the loss of a single rival or constraints on its expansion may have little impact if there is sufficient continued competition by other rivals that prevents the excluding firm from gaining the power to raise or maintain supra-competitive prices. ${ }^{139}$

However, when the excluding firm is a monopolist and its exclusionary conduct raises the costs of the sole independent entrant (or all of the most likely potential entrants) into the market, the analysis should be affected. These conditions can help to support an inference that the costraising conduct likely would give the monopolist power over price. This is one reason why conduct of a monopolist faces a more stringent standard than the same conduct by a firm that lacks market power, as recognized in the case law. As stated by Justice Scalia, "[w]here a defendant maintains substantial market power, his activities are examined through a special lens: Behavior that might otherwise not be of concern to the antitrust laws-or that might be viewed as procompetitive-can take on exclusionary connotations when practiced by a monopolist." 140

${ }^{138}$ The Commission found that McWane had no cognizable efficiency benefits. See McWane at 30-32. Commissioner Wright did not analyze the evidence on this issue. Dissent at 6 n.12.

${ }^{139}$ See infra, Section II. Krattenmaker \& Salop, supra note 18, at 247.

${ }^{140}$ Eastman Kodak Co. v. Image Technical Servs., Inc., 504 U.S. 451, 488 (1992) (Scalia, J., dissenting); see also United States v. Dentsply Int'l, Inc., 399 F.3d 181, 187 (3d Cir. 2005) ("Behavior that otherwise might comply with antitrust law may be impermissibly exclusionary when practiced by a monopolist."); 3B AREEDA \& HOVENKAMP, supra note 11, II 806e. 


\section{McWane's Exclusionary Purpose}

Commissioner Wright's proposed legal standard and analysis also failed to give due consideration to the exclusionary purpose behind McWane's conduct. The case law from Alcoa to Trinko treats evidence of the intent behind the conduct of a monopolist as relevant to understanding the likely effect of the conduct. ${ }^{141}$ Commissioner Wright quoted Microsoft for this long-standing proposition. ${ }^{142}$ Such evidence can provide further support for an inference of harm to competition. ${ }^{143}$ However, Commissioner Wright's actual analytic approach appears to have placed no weight at all on the evidence that McWane's purpose and anticipated effect of adopting its exclusivity program was exclusionary.

The evidence cited by the Commission indicated a purpose to deny Star's access to distributors, raise its distribution costs, and deny Star the scale needed to invest. As detailed by the Commission, starting in the Spring of 2009, Richard Tatman, Vice President and General Manager of McWane's fittings division, recognized that "'we need to make sure that [Star does not] reach any critical market mass that will allow them to continue to invest and receive a profitable return." "144 As a way to impede entry by Star and Sigma, ${ }^{145}$ Mr. Tatman then outlined a strategy called "Force Distribution to Pick their Horse." advantages of this strategy included: (i) "Avoids the job by job auction scenario within a

${ }^{141}$ See United States v. Aluminum Co. of Am., 148 F.2d 416, 432 (2d Cir. 1945); Aspen Skiing Co. v. Aspen Highlands Skiing Corp., 472 U.S. 585, 602-03, 609 (1985); Verizon Commcn's, Inc. v. Trinko, 540 U.S. 398, 409-10 (2004).

${ }^{142}$ Dissent at 9 (citing United States v. Microsoft Corp., 253 F.3d 34, $58-59$ (D.C. Cir. 2001)).

${ }^{143}$ However, an antitrust standard based solely on evidence of anticompetitive intent (whether objective or subjective evidence) clearly would be flawed. For example, see Salop, supra note 52 at 354-57.

${ }^{144}$ McWane at 8 (quoting Mr. Tatman).

145 Sigma abandoned independent entry and became a McWane distributor. See McWane at 11-12.

146 Id. at 9. 
particular distributor"; (ii) "Potentially raises the level of supply concern among contractors"; and (iii) "Forces Star/Sigma to absorb the costs associated with having a more full line before they can secure major distribution[.]" 147 This strategy was then carried out through the Full Support Program.

These statements do not sound like mere, loose "locker-room" puffery. They seemly stated a rational economic plan to raise rivals' costs and prevent Star and Sigma from achieving efficient distribution. This evidence seems to show that McWane's purpose was to foreclose Star's access to both customers and inputs. As a result, it was worthy of due consideration as evidence to help to support an inference of anticompetitive effect. By adopting a narrow legal and economic approach that fails to take into account this type of evidence and the inferences that can be drawn from it, Commissioner Wright's standard would make it harder for the plaintiff to satisfy the burden of proof and increases the potential for false negatives and under-deterrence in cases where the monopolist's purpose is to harm competition.

\section{McWane's Lack of Cognizable Efficiency Benefits}

Efficiency claims have two roles in antitrust analysis. First, the existence of valid efficiency benefits can mean that conduct that is potentially exclusionary can increase competition, rather than reduce it. For example, Sylvania excluded certain distributors from selling its products, but this conduct increased its ability to compete with other manufacturers. ${ }^{148}$ East Jefferson Hospital did not permit patients to choose their own anesthesiologists, but this conduct apparently was able to increase product quality and East Jefferson's ability to compete

\footnotetext{
${ }^{147} I d$. (alteration in original).

${ }^{148}$ Cont'l T.V., Inc. v. GTE Sylvania Inc., 433 U.S. 36, 54-55 (1977).
} 
with the other hospitals in the market. ${ }^{149}$ However, evidence showing a lack of cognizable efficiency benefits or that the efficiency claims are pretextual also can help to support an inference that the purpose and likely effect of the conduct are exclusionary. ${ }^{150}$ This evidence obviously also would establish the invalidity of an opposite presumption that the defendant's exclusive dealing is efficient and procompetitive.

McWane argued that the exclusives helped to preserve its sales so that it could operate its own domestic foundry. McWane's expert also claimed that McWane's exclusives were an attempt to prevent "cherry picking" by customers that would have led to McWane being unable to survive in the market as a full-line producer. ${ }^{151}$ However, the Commission concluded that this justification was unable to explain why McWane could not instead raise the prices for the less common parts. The use of the price system also would appropriately incentivize consumers to use the parts that were less expensive because their production benefited from economies of scale. $^{152}$

149 Jefferson Parrish Hosp. Dist. No. 2 v. Hyde, 466 U.S. 2, $43-44$ (1984) (O'Connor, J., concurring).

${ }^{150}$ See Chicago Bd. of Trade v. United States, 246 U.S. 231, 238 (1918) ("The history of the restraint, the evil believed to exist, the reason for adopting the particular remedy, the purpose or end sought to be attained, are all relevant facts."). Applied to Section 2, the Court in Aspen Skiing inferred anticompetitive purpose from the defendant's lack of a valid efficiency benefits. Aspen Skiing Co. v. Aspen Highlands Skiing Corp., 472 U.S. 585, 608 n.39 (1985) ("[I]ntent to engage in predation may be in the form of ... evidence that the conduct was not related to any apparent efficiency." (citation omitted)). An analogous inference process can be used to exonerate conduct. For example, in Rothery Storage \& Van Co. v. Atlas Van Lines, Inc., 792 F.2d 210 (D.C. Cir. 1986), Judge Bork inferred that the conduct of Atlas Van Lines likely was efficient because Atlas lacked the market power necessary to cause harm competition. Id. at 221.

${ }^{151}$ See McWane at 31.

${ }^{152}$ Suppose that the facts showed that McWane would be unable to raise the prices of some uncommonlyused items because consumers would substitute to imports. In this scenario, the market "but-for" the exclusives would involve the combination of import competition for these uncommon items and competition from Star and others for domestic items, not the unavailability of the uncommonly-used items. 
If McWane's claims had been accepted, such a defense could have far-reaching adverse competitive consequences. Any monopolist with a technology that has scale economies could justify depriving all potential entrants of access to critical inputs on the grounds that entry would cause the monopolist to lose scale that would lead it to raise prices for certain of its products. The significant potential for anticompetitive effects resulting from the misuse of such claims suggests that a monopolist should have to bear a very heavy burden to justify this type of exclusionary conduct.

However, Commissioner Wright's standard did not subject McWane's efficiency claims to this heavy burden. Nor did he even find it necessary to analyze the facts introduced at trial regarding McWane's efficiency claim. His standard requires the plaintiff to show other clear evidence of harm to competition, without any reference to the claimed efficiency benefits being invalid. This decision-making approach appears inefficient in that it fails to utilize all the available evidence that already was contained in the trial record.

Commissioner Wright's standard follows an overly rigid, sequential pattern of burdenshifting. While the burden-shifting framework is a useful conceptual framework, and is particularly useful in pretrial motions, the rigidity after trial is not. Trials are not bifurcated into these separate steps. At the trial, the plaintiff and the defendant provide all their evidence, and then the decision maker decides on the basis of all the evidence. ${ }^{153}$ It is inefficient for the decision maker to ignore relevant evidence in the trial record. Moreover, a bright line division between evidence regarding benefits and separate evidence of harms also may not be valid.

${ }^{153}$ One benefit for this unitary approach is that there are evidentiary economies of scope. It may be more economical to engage in discovery on a set of documents and testimony all issues at once, rather than sequencing discovery. In addition, certain documents or testimony may be relevant for evaluating both harm to competition and procompetitive benefits. 
Evidence on the defendant's stated purpose and evidence of procompetitive benefits claims can be relevant for evaluating the likelihood of competitive harm.

This can be illustrated with a hypothetical example. Suppose that a monopolist an institutes exclusive dealing program that targets all rivals, and there is evidence of anticompetitive purpose. Suppose further that the evidence indicates a lack of procompetitive benefits. That evidence suggests that the anticompetitive theory is more credible and probable than the procompetitive one. It also would rebut a presumption the conduct likely is procompetitive.

\section{Direct Evidence and Causation}

Commissioner Wright concluded that his standard properly raises the burden on the plaintiff after a trial on the merits because "a plaintiff has had ample opportunities to develop direct evidence of anticompetitive effects." "154 Commissioner Wright stated a strong desire for direct evidence of anticompetitive effects. Coupled with his "clear evidence" standard, this placed a heightened and potentially insurmountably high burden on the plaintiff. ${ }^{155}$ Moreover, in this case, his statement did not adequately credit the direct evidence found by the Commission. Instead, his statement ignored certain direct evidence and asked for additional facts on the other direct evidence.

\section{Price Effect}

\footnotetext{
${ }^{154}$ Dissent at $19-20$.

${ }^{155}$ See Microsoft, 235 F.3d at 79 (observing that "no case ... stand[s] for the proposition that, as to $\S 2$ liability in an equitable enforcement action, plaintiffs must present direct proof that a defendant's continued monopoly power is precisely attributable to its anticompetitive conduct").
} 
Commissioner Wright stated that "Complaint Counsel's burden is to show that McWane's conduct caused any price effect", 156 and that the "best and most straightforward way to establish harm to competition is, of course, direct evidence that the exclusive dealing arrangement caused prices to rise and output to fall relative to a but-for world. ${ }^{157} \mathrm{He}$ then criticized Complaint Counsel for failing to introduce such direct price evidence, concluding that "Complaint Counsel makes no effort to establish harm to competition directly, such as by demonstrating that McWane's conduct had a deleterious effect upon price or output in the Domestic Fittings market." ${ }^{158}$ In doing so, Commissioner Wright departed from the Commission opinion, which found that McWane's actions limited Star's sales to such an extent that Star's entry was ineffective in forcing McWane to reduce its prices. This impact on prices was supported by McWane's own internal analysis predicting that Star's (unencumbered) entry into the domestic market would have resulted in lower prices. ${ }^{159}$

The Commission did analyze probative direct pricing evidence. The Commission compared McWane's prices in the market for domestic fittings (where Star entered and where McWane's exclusives applied) to the market for non-domestic fittings (where the exclusives were not applied). As found by the Commission, "McWane continued to sell its domestic fittings into domestic-only specifications at prices that earned significantly higher gross profits

\footnotetext{
${ }^{156}$ Dissent at 36-37 n.43 (italics in original).

${ }^{157}$ Dissent at 19.

${ }^{158}$ Dissent at 5.

${ }^{159}$ See McWane at 27. The Commission also quoted from a McWane document on this point that "Whether we end up with Star as a complete or incomplete domestic supplier my chief concern is that the domestic market gets creamed from a pricing standpoint just like the non-domestic market has been driven down in the past." Id. at 31 .
} 
than for non-domestic fittings, which faced greater competition. IDF 1091." ${ }^{160}$ This is direct evidence of anticompetitive effects. The Commission also cited to McWane's own expert, Dr. Normann, who "concluded that Star's presence in the domestic fittings market in several states did not produce lower prices. IDF 1090." ${ }^{161}$ This also is direct evidence.

Perhaps because of the skepticism inherent in his clear evidence standard, Commissioner Wright appeared to ignore both these types of direct price-effect evidence. He did not mention the finding that prices for domestic fittings led to higher gross profits, nor the finding that McWane's prices did not fall in response to Star's entry. He chose instead merely to dispute the probative value of the Complaint Counsel's proffered additional evidence regarding McWane's pricing predictions and its higher announced (as opposed to transaction) prices. ${ }^{162}$

The evidence comparing gross profit margins for domestic versus the non-domestic fittings is very useful because it is a type of economic "natural experiment."163 It can provide an "estimate of the prices and output that would have occurred during the relevant time period had McWane not engaged in the challenged conduct."164 Similar direct evidence also was used in the Staples merger case. ${ }^{165}$ In addition, the use of gross profit margins controls for possible cost

${ }^{160}$ McWane at 18.

${ }^{161} I d$

${ }^{162}$ He noted that the evidence of higher prices involved only "announced" prices, not transactions prices. He also suggested that the price increases could have been the result of higher demand or an increase in McWane's costs. Dissent at 36 n.43.

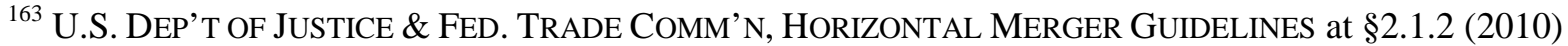
("reliable evidence based on variations among similar markets"), available at http://ftc.gov/os/2010/08/100819hmg.pdf.

${ }^{164}$ Dissent at 5 n. 10

${ }^{165}$ For example, in the Staples merger case, the Court found significant the finding that prices were lower in the markets where Staples and its potential merger partner, Office Depot, competed, than where they did not. As stated by the court, "direct evidence shows that by eliminating Staples' most significant, and in many markets only, rival, this merger would allow Staples to increase prices or otherwise maintain price 
changes. Thus, it seems surprising that Commissioner Wright would have placed no probative weight on it.

While Commissioner Wright's concern about announced versus transaction prices could be relevant to the issue of whether McWane increased prices, it would have less bearing on the question of whether McWane's conduct allowed it to maintain monopoly prices. McWane was an incumbent monopolist, already charging monopoly prices at the time it launched the Full Support Program. Thus, evidence that McWane's prices did not fall after Star's entry (as opposed to evidence of price increases) would be the more relevant direct evidence. And the more plausible inference would be that McWane's conduct towards Star allowed it to maintain monopoly prices. ${ }^{166}$ This conclusion is strengthened by the concession of McWane's own expert. This view is also consistent with McWane's concern that prices would fall following Star's entry. ${ }^{167}$

\section{Star's Lost Sales}

Commissioner Wright also criticized Complaint Counsel for failing to identify any lost sales specifically caused by McWane's exclusive dealing. Courts are reluctant to impose such strict causation requirements on Section 2 plaintiffs, particularly in cases involving the exclusion

at an anti-competitive level.” Fed. Trade Comm'n v. Staples, Inc., 970 F. Supp. 1066, 1083 (D.D.C. 1997).

${ }^{166}$ The relevant price comparison is the price with versus without the alleged anticompetitive conduct. A comparison can involve comparable products rather than over time, as noted below. A similar issue arose in the context of the Staples merger case. As the Staples court explained, "when the Court discusses 'raising' prices it is also with respect to raising prices with respect to where prices would have been absent the merger, not actually an increase from present price levels." Staples, Inc., 970 F. Supp.at 1082 n.14.

${ }^{167}$ See McWane at 27 ("McWane itself recognized that if Star entered, prices in the domestic market would likely fall just like in the imported market.") Commissioner Wright rejects the relevance of McWane's predictions. Dissent at 36, n.43 ("McWane's prediction is 'simply not evidence."') 
of new entrants. ${ }^{168}$ As a result, where a defendant with monopoly power attempts to exclude an emerging threat, a strict "but for" causation need not be established. ${ }^{169}$ Moreover, Complaint Counsel did show lost sales by Star that were the direct result of the Full Support Program. As the Commission found, following the announcement of the Full Support Program, McWane distributors cancelled pending orders with Star and pulled their bid requests. ${ }^{170}$ Such actions caused Star to readjust its sales estimates and discontinue negotiations to purchase a domestic foundry. ${ }^{171}$ This is another way in which Commissioner Wright raised the burden of production. Under prevailing case law, the evidence would seem to have been clear enough to find the requisite causation.

\section{Effect on Star's Market Share and Growth Rate}

Commissioner Wright suggested that Star's growth rate was identical before and after McWane stopped its exclusive dealing policy. ${ }^{172}$ According to Commissioner Wright, "[t]he

${ }^{168}$ As the Microsoft court opined, "when exclusionary conduct is aimed at producers of nascent competitive technologies," "[t]o some decree, "the defendant is made to suffer the uncertain consequences of its own undesirable conduct." "United States v. Microsoft Corp., 253 F.3d 34, 79 (D.C. Cir. 2001) (quoting 3 PHILliP AREEDA \& HERBERT HOVENKAMP, ANTITRUST LAW II 651c, at 78 (1996)); see also Andrew I. Gavil, Exclusionary Distribution Strategies by Dominant Firms: Striking a Better Balance, 72 ANTITRUST L.J. 3, 59-60 (2004) ("[T] he exclusion of the less efficient firm might not have harmed competition at that precise moment because the rival had yet to receive its potential, but Section 2's horizon should not be so clipped if it is to function as an adequate deterrent to strategic behavior that impairs long-run competition."); Sunbeam Television Corp. v. Nielsen Media Research, Inc., 763 F. Supp. 2d 1341, 1356 (S.D. Fla. 2011) ("Obviously, a monopolist should not be rewarded for eliminating competition in its incipiency.").

${ }^{169}$ Microsoft, 253 F.3d at 79 ("We may infer causation when exclusionary conduct is aimed at producers of nascent competitive technologies as well as when it is aimed at producers of established substitutes.").

${ }^{170}$ See McWane at 10, 23.

${ }^{171}$ See id. at 25.

${ }^{172}$ Dissent at 45; see also id. at 45 n.51 ("McWane did not enforce the Full Support Program against any distributor after April 13, 2010."). We note that the Commission found that the exclusives did not end. See McWane at 39-40. However, for purposes of the analysis here, we will assume that the exclusives did end. 
most plausible inference to draw from these particular facts is that the Full Support Program had almost no impact on Star's ability to enter and grow its business, which, under the case law, strongly counsels against holding that McWane's conduct was exclusionary.","173

In our view, Commissioner Wright's analysis of Star's growth rate after the exclusivity ended ignored certain relevant economic analysis. Commissioner Wright also observed that Star's market share doubled after the exclusivity period ended. ${ }^{174}$ A larger market share means that the entrant has taken more sales away from the monopolist, which in turn would increase the monopolist's incentive to cut prices to recover those lost sales. Thus, Star's higher market share would seem to suggest that Star provided more of a competitive constraint on McWane after the exclusivity ended than before, not the opposite.

Moreover, even if Star had not achieved a higher market share after the exclusives ended, there are two other explanations for its lack of greater growth that would cast doubt on Commissioner Wright's inference that the exclusives failed to have any effect on market prices and output. First, Star's market share and growth rate after the exclusives ended would depend on McWane's own post-exclusivity conduct. If McWane responded to Star's potential for greater expansion after the exclusives ended by cutting its own prices below the monopoly level in order to maintain its own market share, that competitive response would have reduced Star's growth. But at the same time, this outcome in the period after the exclusivity ended still would be consistent with there being anticompetitive effects on prices during the period of exclusivity.

\footnotetext{
${ }^{173}$ Dissent at 46.

${ }^{174}$ Dissent at 36 n.43 (Star "having twice as high a market share in 2011"). Star's market share increase would be more relevant than its percentage growth rates in the two periods. For example, if Star's market share were to triple from $1 \%$ to $3 \%$, that growth would provide less of a competitive constraint than if Star's market share only doubled -- but from $5 \%$ up to $10 \%$.
} 
This explanation instead suggests that those harmful effects might have been reduced or eliminated in the period after the exclusively ended.

Second, lack of faster growth by Star in the period after the exclusivity period ended could have been caused by the longer-term adverse effects of the exclusives. In a dynamic market, actions in one period can have longer term effects on competition and output. This outcome could occur if Star's failure to grow sufficiently during the period of exclusivity constrained its ability to invest subsequently. ${ }^{175}$ In fact, one of McWane's stated goals was to delay Star so that it would not continue to invest. ${ }^{176}$ In this regard, the period of exclusive dealing may have been a unique window of opportunity for entry afforded by the increased demand resulting from the ARRA regulations. ${ }^{177}$ Indeed, as Commissioner Wright noted, ARRA-funded projects had to be under contract or under construction by February 2010, and thereafter demand for domestic pipefittings decreased. ${ }^{178}$ If this window passed without Star obtaining sufficient order commitments, building a foundry may well have been rendered less

\footnotetext{
${ }^{175}$ The evidence showed that at the time McWane launched the Full Support Program, Star was in the midst of negotiating to purchase a foundry. After McWane announced its program and distributors began withdrawing their Star orders, Star was forced to abandon its plan to acquire a foundry due to a reduction in expected sales. See McWane at 25.

${ }^{176}$ See McWane at 8 (“' [W] need to make sure that they don't reach any critical market mass that will allow them to continue to invest and receive a profitable return."' (citation omitted)). Star also may have found it harder to obtain financing. Imperfectly informed lenders may not have been confident that Star's failure was due solely to McWane's exclusive dealing or that the elimination of its exclusive dealing was permanent and, therefore, rationally would have refused to extend the necessary credit. For discussion of the impact of imperfect information on outside financing constraints, see Joseph E. Stiglitz \& Andrew Weiss, Credit Rationing in Markets with Imperfect Information, 71 (3) AM. ECON. REV. 393 (1981); Patrick Bolton et al., Predatory Pricing: Strategic Theory and Legal Policy, 88 GEO. L.J. 2239 (2000).

${ }^{177}$ Construction needed to be contracted or commenced within 12 months of the enactment of the ARRA. McWane at 7-8.

${ }^{178}$ Dissent at 36 n.43.
} 
economically feasible. ${ }^{179}$ Thus, this explanation for the lack of faster growth by Star would be consistent with there being anticompetitive effects both during and after the period of exclusivity.

These alternative economic explanations mean that it is unlikely that the facts about Star's growth rate discussed by Commissioner Wright could be determinative for the defendant. But, Commissioner Wright did not take these possibilities into account in demanding that this evidence be produced by Complaint Counsel. This is another way in which his statement took a narrow approach to the relevant economic analysis.

At the same time that his economic analysis was narrowed, Commissioner Wright placed a broad burden on the plaintiff. If Commissioner Wright's expansive approach to the plaintiff's burden of production were embraced, there is almost no limit to the potential evidence that conceivably could be demanded by a skeptical judge. For example, suppose that the evidence showed that prices fell after the exclusives clearly ended. Even so, Commissioner Wright could have argued that this finding would not satisfy his "clear evidence" standard, which would require showing that it was the elimination of the exclusives that caused the prices to fall. $\mathrm{He}$ could say that there were a "host of other factors" that equally could explain the price decrease. ${ }^{180}$ For example, he could suggest that the price decreases might have been caused by a decrease in demand for domestic fittings, or by a decrease in costs, or by McWane revising its estimate of the market demand elasticity, or by Star changing its pricing strategy or ramping up

\footnotetext{
179 This window also raises a more general question about a before/after comparison of Star's sales. Construction takes time, so a failure of Star to obtain orders during the period of exclusivity might have led to Star making fewer deliveries after the exclusivity was no longer enforced.

${ }^{180}$ Dissent at 36 n.43 (discussing McWane's earlier announced price increases)
} 
direct distribution. ${ }^{181}$ Tracking down all these possibilities would require more evidence to be produced and that evidence conceivably also could be further questioned. It would not make economic sense for Complaint Counsel to be required to produce any and all relevant evidence that possibly could be available. ${ }^{182}$

\section{Conclusion}

For all these reasons, we disagree with Commissioner Wright's economic analysis and proposed legal standard. His proposed legal standard is not a proper "enquiry meet for the case." "183 Instead, his approach to the economic analysis and the law would lead to excessive false negatives, under-enforcement and under-deterrence. It would provide perverse incentives for monopolists to use exclusive dealing to exclude new entrants, even where the exclusives lack cognizable efficiency benefits. As a result, there is a large risk that consumers and the competitive process would be harmed by his proposed standard.

${ }^{181}$ In this regard, Commissioner Wright stated his belief that demand fell in 2011, relative to 2010. He also suggested that McWane cost increases could have been the cause of its earlier price increase announcement. Dissent at 36 n.43.

${ }^{182}$ Such an expansive evidentiary burden of production obviously would make antitrust enforcement much more difficult and lead to false negatives and under-deterrence. Even if all the evidence feasibly could be produced, this approach would not be efficient since evidence is costly to produce. There is often no limit to the amount of relevant evidence that parties potentially can provide to a court, if the only test is potential availability and if the cost and time delay of producing the evidence are ignored.

${ }^{183}$ Cal. Dental Ass'n. v. FTC, 526 U.S. 756, 781 (1999). 